\title{
Validation of OMI Tropospheric N02 Observations During INTEX-B and Application to Constrain NOX Emissions Over the Eastern United States and Mexico
}

\section{Citation}

Boersma, K. F., Daniel J. Jacob, E.J. Bucsela, A. E. Perring, R. Dirksen, R. J. van der A, Robert M. Yantosca, R. J. Park, M. O. Wenig, T. H. Bertram, and R. C. Cohen. 2008. Validation of OMI tropospheric NO2 observations during INTEX-B and application to constrain NOx emissions over the eastern United States and Mexico. Atmospheric Environment 42(19): 4480-4497.

\section{Published Version}

doi:10.1016/j.atmosenv.2008.02.004

\section{Permanent link}

http://nrs.harvard.edu/urn-3:HUL.InstRepos:3579187

\section{Terms of Use}

This article was downloaded from Harvard University's DASH repository, and is made available under the terms and conditions applicable to Other Posted Material, as set forth at http:// nrs.harvard.edu/urn-3:HUL.InstRepos:dash.current.terms-of-use\#LAA

\section{Share Your Story}

The Harvard community has made this article openly available.

Please share how this access benefits you. Submit a story.

\section{Accessibility}




\title{
Validation of OMI tropospheric $\mathrm{NO}_{2}$ observations during INTEX-B and application to constrain $\mathrm{NO}_{x}$ emissions over the eastern United States and Mexico
}

\author{
K.F. Boersma ${ }^{a, *}$, D.J. Jacob ${ }^{\text {a }}$, E.J. Bucsela ${ }^{\mathrm{b}}$, A.E. Perring ${ }^{\mathrm{c}}$, R. Dirksen ${ }^{\mathrm{d}}$, \\ R.J. van der $\mathrm{A}^{\mathrm{d}}$, R.M. Yantosca ${ }^{\mathrm{a}}$, R.J. Park ${ }^{\mathrm{a}}$, M.O. Wenig ${ }^{\mathrm{b}}$, \\ T.H. Bertram ${ }^{\mathrm{c}}$, R.C. Cohen ${ }^{\mathrm{c}}$ \\ ${ }^{a}$ School of Engineering and Applied Sciences, Harvard University, Cambridge, 02138 MA, USA \\ ${ }^{\mathrm{b}}$ GEST Program, University of Maryland, Baltimore, MD, USA \\ ${ }^{\mathrm{c}}$ Department of Chemistry, University of California, Berkeley, CA, USA \\ ${ }^{\mathrm{d} C l i m a t e}$ Observations Department, Royal Netherlands Meteorological Institute, De Bilt, The Netherlands
}

Received 22 January 2008; accepted 5 February 2008

\begin{abstract}
We compare tropospheric $\mathrm{NO}_{2}$ column measurements from the Ozone Monitoring Instrument (OMI) aboard the EOS Aura satellite with coincident in situ aircraft measurements on vertical spirals over the southern United States, Mexico, and the Gulf of Mexico during the INTEX-B campaign in March 2006. Good correlation with no significant bias $\left(r^{2}=0.67\right.$, slope $\left.=0.99 \pm 0.17, n=12\right)$ is found for the ensemble of comparisons when the aircraft could spiral sufficiently low to sample most of the $\mathrm{NO}_{2}$ column. Urban spirals where large extrapolations were needed below the aircraft floor $(1000 \mathrm{ft})$ showed poorer agreement. We use the OMI observations together with a global chemical transport model (GEOS-Chem) to estimate emissions of nitrogen oxides over the eastern United States and Mexico in March 2006. Comparison to EPA's National Emissions Inventory 1999 (NEI99) calls for a decrease in power plant emissions and an increase in on-road vehicle emissions relative to that inventory. The rise in vehicular emissions is offsetting the reduction in power plant and industry emissions. These findings are consistent with independent assessments. Our OMI-derived emission estimates for Mexico are higher by a factor of $2.0 \pm 0.5$ than bottom-up emissions, similar to a comparison between the recently released Mexican NEI99 inventory and the bottom-up showing that the Mexican NEI99 inventory is $1.6-1.8 \times$ higher.
\end{abstract}

(C) 2008 Elsevier Ltd. All rights reserved.

Keywords: INTEX-B; Validation; OMI; Tropospheric $\mathrm{NO}_{2} ; \mathrm{NO}_{x}$ emissions

\section{Introduction}

Nitrogen oxides $\left(\mathrm{NO}_{x}=\mathrm{NO}+\mathrm{NO}_{2}\right)$ are shortlived (3-24h at the surface) species that catalyze

${ }^{*}$ Corresponding author.

E-mail address: boersma@seas.harvard.edu (K.F. Boersma). ozone production and contribute to aerosol formation in the troposphere. Human activity is a major 
source of $\mathrm{NO}_{x}$ in the troposphere, but it is difficult to quantify the influence of $\mathrm{NO}_{x}$ emissions on atmospheric chemistry because there are large uncertainties as to when, where, and how much $\mathrm{NO}_{x}$ has been emitted. Since 1995, satellite retrievals of tropospheric $\mathrm{NO}_{2}$ columns extend the existing ground-based and aircraft observational database with ever more spatial detail and coverage. These satellite observations offer the possibility to improve our understanding of $\mathrm{NO}_{x}$ sources and chemistry by testing or improving emission inventories through inverse (top-down) modelling techniques (e.g. Martin et al., 2003).

For top-down emission estimates to be meaningfull, the satellite retrievals need to be validated and their errors need to be characterized. This is especially relevant for retrievals of tropospheric $\mathrm{NO}_{2}$ that necessarily rely on assumptions regarding the state of the atmosphere (e.g. $\mathrm{NO}_{2}$ profile shape). Studies into error budgets for retrievals from the Global Ozone Monitoring Experiment (GOME), the Scanning Imaging Absorption Spectrometer for Atmospheric CHartographY (SCIAMACHY) and the Ozone Monitoring Instrument (OMI) on board EOS Aura indicate uncertainties on the order of $30-60 \%$ for individual measurements (Richter and Burrows, 2002; Martin et al., 2002; Boersma et al., 2004, 2007). Moreover, comparisons of GOME $\mathrm{NO}_{2}$ retrievals from three different groups showed systematic differences in $\mathrm{NO}_{2}$ columns of $10-50 \%$ for some regions and seasons (van Noije et al., 2006).

Until now, most evaluation of GOME and SCIAMACHY $\mathrm{NO}_{2}$ retrievals has relied on serendipitous overlap with other measurements (e.g. ground-based Schaub et al., 2006 or aircraft-based Martin et al., 2004). These comparisons relied heavily on assumptions on the spatial and temporal representativity of the validation data for satellite scenes with sizes of $60 \times 30 \mathrm{~km}^{2}$ (SCIAMACHY) and $320 \times 40 \mathrm{~km}^{2}$ (GOME). In addition, studies using in situ concentrations measured at groundlevel only (e.g. Ordóñez et al., 2006) had to make strong assumptions on the vertical distribution of $\mathrm{NO}_{2}$ in the unobserved part of the troposphere. Aircraft measurements of $\mathrm{NO}_{2}$ profiles coinciding in space and time with satellite observations allow a more direct validation opportunity as shown by Heland et al. (2002) and Martin et al. (2006).

One of the goals of the Intercontinental Chemical Transport Experiment-Phase B (INTEX-B) DC-8 aircraft experiment conducted in March 2006 from
Houston, Texas, was to validate satellite retrievals of tropospheric composition, in particular $\mathrm{NO}_{2}$ columns from OMI (Levelt et al., 2006) launched aboard the Aura satellite in July 2004. This was an important opportunity for validation, for three reasons:

- The validation profiles (spirals) were collocated and coincident with the satellite overpasses. The spiral radius $(\sim 20 \mathrm{~km})$ was consistent with the OMI pixel size $\left(13 \times 24 \mathrm{~km}^{2}\right.$ at nadir $)$.

- The vertical profiling of the DC-8 extended from the boundary layer up to $12 \mathrm{~km}$ altitude, thus virtually sampling the whole troposphere.

- The INTEX-B scientific focus of characterizing the outflow of pollution from Mexico City provided independent $\mathrm{NO}_{2}$ observations close to source regions as well as in downwind and remote areas, allowing for validation under a large range of conditions.

Validation of OMI tropospheric $\mathrm{NO}_{2}$ columns for the INTEX-B conditions has particular value for better constraining North American sources of $\mathrm{NO}_{x}$. Recent regulation from the U.S. Environmental Protection Agency has imposed sharp decreases in emissions from power plants to abate ozone pollution (Frost et al., 2006), and OMI offers an opportunity to verify this. Kim et al. (2006) inferred summertime reductions in $\mathrm{NO}_{x}$ from power plants from SCIAMACHY observations and the question remains whether these reductions can also be observed outside of the summertime season. OMI, with its daily global coverage and small pixel sizes, is well suited to constrain $\mathrm{NO}_{x}$ emissions. This has recently been demonstrated by Wang et al. (2007b) in a paper showing that aggressive measures to restrict traffic issued by the Beijing municipal authorities led to reduced $\mathrm{NO}_{x}$ emissions that were detected by the OMI near-real time (NRT) $\mathrm{NO}_{2}$ retrieval. In this paper we constrain $\mathrm{NO}_{x}$ emissions over the United States, and over Mexico, where emission inventories for Mexican $\mathrm{NO}_{x}$ sources are still highly uncertain (Kuhns et al., 2005).

\section{Validation of $\mathrm{OMI} \mathrm{NO}_{2}$ columns with INTEX-B aircraft profiles}

\subsection{Ozone monitoring instrument}

The Dutch-Finnish OMI on NASA's EOS Aura satellite is a nadir-viewing imaging spectrograph 
measuring direct and atmosphere-backscattered sunlight in the ultraviolet-visible (UV-VIS) range from 270 to $500 \mathrm{~nm}$ (Levelt et al., 2006). EOS Aura was launched on 15 July 2004 and traces a Sunsynchronous, polar orbit at approximately $705 \mathrm{~km}$ altitude with a period of $100 \mathrm{~min}$ and a local equator crossing time between 13:40 and 13:50 local time. EOS Aura is part of the so-called A-Train, a group of formation-flying satellites equipped with instruments focusing on climate change. OMI has two two-dimensional CCD detectors that record the (ir)radiance spectrum in one direction, and observe the Earth's atmosphere with a $114^{\circ}$ field of view, distributed over 60 discrete viewing angles, perpendicular to the flight direction. OMI's wide field of view corresponds to a $2600 \mathrm{~km}$ wide spatial swath on the Earth's surface for one orbit, large enough to achieve complete global coverage in one day. OMI pixels are $13-26 \mathrm{~km}$ along track, and $24-135 \mathrm{~km}$ across track, depending on the viewing zenith angle.

OMI has three spectral channels: UV1 $(270-310 \mathrm{~nm})$ and UV2 $(310-365 \mathrm{~nm})$ are covered by CCD1. CCD2 covers the VIS channel from $365-500 \mathrm{~nm}$ with a spectral sampling of $0.21 \mathrm{~nm}$ and a spectral resolution of $0.63 \mathrm{~nm}$. It is in this channel that the spectral features of $\mathrm{NO}_{2}$ are most prominent. The spectral sampling rate (resolution/sampling) is $\sim 3$, large enough to avoid spectral undersampling or aliasing difficulties in the spectral fitting process. During nominal operations OMI takes one measurement of the solar irradiance per day.

\section{2. $\mathrm{NRT} \mathrm{OMI}$ tropospheric $\mathrm{NO}_{2}$ retrieval}

We use here NRT tropospheric $\mathrm{NO}_{2}$ columns (Boersma et al., 2007) retrieved by KNMI/NASA (version TM4NO2A-OMI v0.8, February 2006). On-line OMI NRT retrieval versions are subject to improvements, but v0.8-data are available upon request. The NRT data are available to the scientific community (www.temis.nl) within $3-4 \mathrm{~h}$ of the $(\sim 13: 40$ local time) observation with potential benefits for air quality monitoring and forecasting. This retrieval is independent from the OMI standard product at NASA Goddard Earth Sciences Data and Information Services Center (GES-DISC, Boersma et al., 2002; Bucsela et al., 2006). Validation of the standard product is described elsewhere (Brinksma et al., 2008; Bucsela et al., 2008; Wenig et al., 2008). Bucsela et al. (2008) compare standard product and NRT tropospheric $\mathrm{NO}_{2}$ columns, and find considerable differences between the two with $\mathrm{NO}_{2}$ from the NRT generally being higher than from the standard product, depending on the regression method and extrapolation assumptions used.

Total slant columns are determined by non-linear least squares fitting of a set of reference spectra $\left(\mathrm{NO}_{2}\right.$, ozone, Ring effect) and a low-order polynomial to reflectance spectra (proportional to the ratio of the radiance at top-of-atmosphere and the solar irradiance spectra) observed by OMI in the 405-465 nm window. Instrument calibration errors lead to spurious across-track variability in the $\mathrm{NO}_{2}$ slant columns that is corrected with a low-pass filtering procedure (Boersma et al., 2007). The filtering retains slant column variation with satellite viewing angle, while suppressing spurious jumps in slant columns from one viewing angle to the other. After this correction, slant column uncertainty is estimated to be $\sim 0.7 \times 10^{15} \mathrm{~mol} \mathrm{~cm}^{-2}$. Stratospheric $\mathrm{NO}_{2}$ is estimated by assimilating $\mathrm{NO}_{2}$ slant columns in the TM4 chemistry-transport model.

Tropospheric slant columns are obtained by subtracting the stratospheric slant column from the total slant column and are subsequently converted into vertical columns by applying the tropospheric air mass factor (AMF, Palmer et al., 2001). The temperature dependence of the $\mathrm{NO}_{2}$ cross section is accounted for using ECMWF temperature profiles for every OMI viewing scene as described in Boersma et al. (2004). AMFs are calculated using a radiative transfer (forward) model (DAK, Stammes, 2001) and our current best estimates of the forward model parameters cloud fraction, cloud pressure, surface albedo and pressure, and a priori profile shape. Cloud parameters are obtained from the $\mathrm{OMI} \mathrm{O}_{2}-\mathrm{O}_{2}$ algorithm (Acarreta et al., 2004). A comparison of cloud distributions from the SCIAMACHY FRESCO (Koelemeijer et al., 2001) and the OMI $\mathrm{O}_{2}-\mathrm{O}_{2}$ algorithm showed consistency with mean differences between FRESCO and OMI cloud fractions $<0.01$ and cloud pressures $<60 \mathrm{hPa}$ (Boersma et al., 2007). Monthly varying surface albedo fields are from a combination of the databases by Herman and Celarier (1997) and Koelemeijer et al. (2003) at a resolution of $1^{\circ} \times 1.25^{\circ}$. A priori $\mathrm{NO}_{2}$ profiles and surface pressure for every OMI pixel at 13:30 local time are specified by TM4 at $3^{\circ} \times 2^{\circ}$.

Total uncertainty in the OMI retrievals of tropospheric $\mathrm{NO}_{2}$ columns over source regions is for the larger part determined by the AMF calculation due to uncertainty in albedo, cloud parameters and 


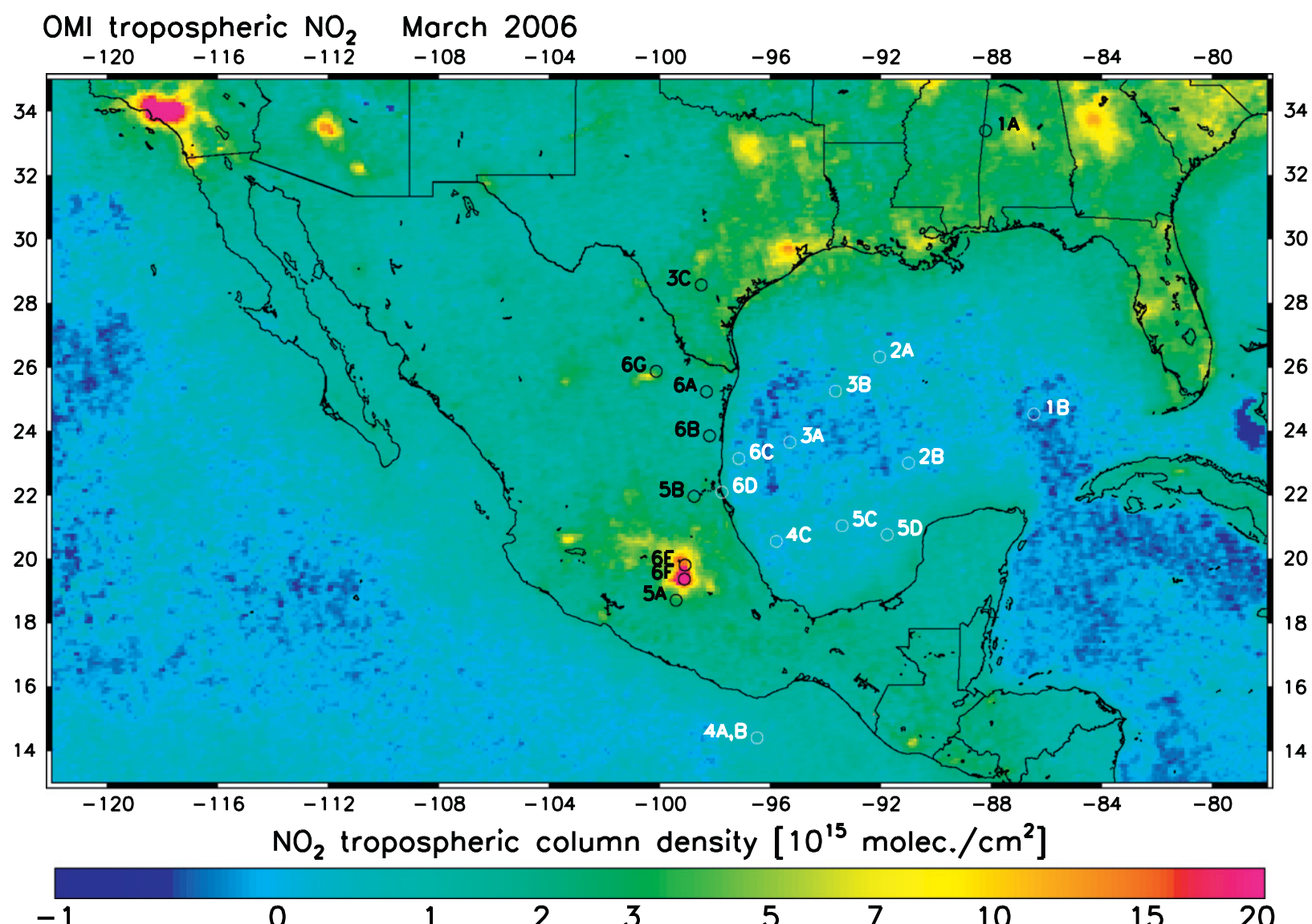

Fig. 1. Monthly mean tropospheric $\mathrm{NO}_{2}$ column in March 2006 from OMI for cloud-free situations (cloud radiance $<50 \%$ ). The circles indicate the location of aircraft profiles over sea (white) and land (black). 1A stands for flight 1, first validation spiral (A). Details on validation profiles can be found in Table 1 .

aerosols, and the a priori profile. The 1-sigma uncertainty for an individual OMI retrieval can be estimated as a base component from the spectral fitting and stratospheric correction, plus a relative error from the AMF uncertainty. The base component is in the $0.5-1.5 \times 10^{15} \mathrm{~mol} \mathrm{~cm}^{-2}$ range depending on the AMF. The relative error is in the $10-40 \%$ range and may include unknown spatial undersampling errors because the a priori (albedo, surface pressure, profile shape) information is available only at coarse resolution compared to the OMI pixel size as discussed in Boersma et al. (2007) and Schaub et al. (2007). OMI retrievals over locations with extreme aerosol loadings such as Mexico City may be subject to above-average aerosol error contributions.

\subsection{Aircraft observations}

We use $\mathrm{NO}_{2}$ observations collected from the DC8 aircraft during the six INTEX-B science flights conducted from Houston in March 2006. The instrumented DC-8 spiraled (up or down) during OMI overpasses with a radius of approximately $20 \mathrm{~km}$ through the $0.3-12.0 \mathrm{~km}$ column. In addition, we derive profiles from ascent and descent flights that covered a large vertical portion of the troposphere over a limited horizontal domain. Fig. 1 and Table 1 give an overview of these profiles.

$\mathrm{NO}_{2}$ on the DC- 8 was measured by laser-induced fluorescence (LIF) (Thornton et al., 2003). In brief, an air sample is pulled into the instrument wherein laser light is used to excite the $\mathrm{NO}_{2}$ in the sample. The laser frequency is alternately tuned between the peak absorption of a strong resonant feature (10 s) and an offline position in the weak continuum absorption $(5 \mathrm{~s})$. The difference between the two signals is directly proportional to the $\mathrm{NO}_{2}$ mixing ratio (Thornton et al., 2000; Cleary et al., 2002). The precision of the $\mathrm{NO}_{2}$ measurements depends on 
Table 1

Overview of DC-8 validation profiles during INTEX-B in March 2006

\begin{tabular}{|c|c|c|c|c|c|c|c|c|}
\hline Date & Profile, type & $\begin{array}{l}\text { Lat. } \\
\left({ }^{\circ} \mathrm{N}\right)\end{array}$ & $\begin{array}{l}\text { Lon. } \\
\left({ }^{\circ} \mathrm{W}\right)\end{array}$ & $\begin{array}{l}\text { Time } \\
\text { (UT) }\end{array}$ & $\begin{array}{l}\text { Pressure } \\
\text { range }(\mathrm{hPa})\end{array}$ & $\begin{array}{l}\text { DC-8 } \\
\left(10^{15} \mathrm{~mol} \mathrm{~cm}^{-2}\right)\end{array}$ & $\begin{array}{l}\text { OMI } \\
\left(10^{15} \mathrm{~mol} \mathrm{~cm}^{-2}\right)\end{array}$ & $\begin{array}{l}\text { No. of } \\
\text { pixels }\end{array}$ \\
\hline $4 \mathrm{March}$ & 1A, spiral & 33.4 & 88.2 & $18: 10$ & $979-218$ & $2.03 \pm 0.52$ & $2.55 \pm 1.56$ & 29 \\
\hline 4 March & 1B, spiral & 24.5 & 86.5 & $20: 34$ & $970-331$ & $0.71 \pm 0.23$ & $-0.38 \pm 0.79$ & 21 \\
\hline 9 March & $2 \mathrm{~A}$, ascent & 26.3 & 92.0 & $18: 29$ & $986-318$ & $0.61 \pm 0.12$ & $-0.02 \pm 0.34$ & 10 \\
\hline 9 March & 2B, spiral & 23.0 & 91.0 & $19: 42$ & $983-226$ & $0.49 \pm 0.07$ & $0.07 \pm 0.36$ & 16 \\
\hline 11 March & $3 \mathrm{~A}$, ascent & 23.7 & 95.3 & $17: 14$ & $975-581$ & $1.05 \pm 0.20$ & $1.03 \pm 0.40$ & 7 \\
\hline 11 March & $3 \mathrm{~B}$, descent & 25.3 & 93.6 & $17: 54$ & $976-376$ & $0.98 \pm 0.14$ & $0.55 \pm 0.34$ & 17 \\
\hline 11 March & $3 \mathrm{C}$, descent & 28.6 & 98.5 & $23: 27$ & $957-585$ & $1.42 \pm 0.28$ & $2.02 \pm 0.35$ & 3 \\
\hline 12 March & $4 \mathrm{~A}$, descent & 14.5 & 96.4 & $21: 10$ & $985-557$ & $0.28 \pm 0.10$ & $0.20 \pm 0.51$ & 1 \\
\hline 12 March & $4 \mathrm{~B}$, spiral & 14.3 & 96.5 & $21: 29$ & $985-468$ & $0.49 \pm 0.18$ & $0.44 \pm 0.62$ & 19 \\
\hline 12 March & $4 \mathrm{C}$, ascent & 20.6 & 95.8 & $23: 29$ & $967-383$ & $0.47 \pm 0.07$ & $-0.07 \pm 0.97$ & 2 \\
\hline 16 March & $5 \mathrm{~A}$, descent & 18.7 & 99.4 & $17: 13$ & $736-376$ & $6.98 \pm 2.50$ & $6.54 \pm 2.52$ & 6 \\
\hline 16 March & $5 \mathrm{~B}$, ascent & 22.0 & 98.8 & $18: 11$ & $970-427$ & $3.39 \pm 0.59$ & $1.81 \pm 0.49$ & 3 \\
\hline 16 March & 5C, descent & 21.0 & 93.4 & 19:02 & $983-706$ & $0.41 \pm 0.24$ & $0.10 \pm 0.28$ & 2 \\
\hline 16 March & 5D, spiral & 20.8 & 91.8 & $19: 42$ & $983-200$ & $0.69 \pm 0.13$ & $0.13 \pm 0.58$ & 20 \\
\hline 19 March & $6 \mathrm{~A}$, descent & 25.2 & 98.3 & $17: 53$ & $938-639$ & $1.01 \pm 0.25$ & $1.60 \pm 0.47$ & 7 \\
\hline 19 March & $6 \mathrm{~B}$, ascent & 23.9 & 98.2 & $18: 17$ & $922-692$ & $1.54 \pm 0.45$ & $1.69 \pm 0.58$ & 12 \\
\hline 19 March & $6 \mathrm{C}$, descent & 23.1 & 97.1 & $18: 30$ & $959-693$ & $1.77 \pm 0.55$ & $0.43 \pm 0.48$ & 10 \\
\hline 19 March & $6 \mathrm{D}$, ascent & 22.1 & 97.8 & $18: 51$ & $965-729$ & $2.36 \pm 0.70$ & $1.45 \pm 0.65$ & 13 \\
\hline 19 March & $6 \mathrm{E}$, descent & 19.8 & 99.1 & $19: 40$ & $762-428$ & $7.26 \pm 2.45$ & $10.29 \pm 2.14$ & 4 \\
\hline 19 March & $6 \mathrm{~F}$, ascent & 19.4 & 99.1 & $20: 04$ & $748-216$ & $2.84 \pm 1.10$ & $7.17 \pm 3.62$ & 4 \\
\hline 19 March & $6 \mathrm{G}$, ascent & 25.9 & 100.2 & $21: 47$ & $922-572$ & $3.60 \pm 0.51$ & $2.97 \pm 1.66$ & 6 \\
\hline
\end{tabular}

laser power, background noise, and signal strength $\left(\mathrm{NO}_{2}\right.$ mixing ratio).

We estimate tropospheric $\mathrm{NO}_{2}$ columns from the DC-8 observed $\mathrm{NO}_{2}$ mixing ratios as follows:

- We use the 1-s mixing ratio observations from the Berkeley TD-LIF instrument with a precision of $\pm 23 \mathrm{ppt}$ at $1000 \mathrm{hPa}$ and $\pm 46 \mathrm{ppt}$ at $200 \mathrm{hPa}$. We average LIF-observed $\mathrm{NO}_{2}$ mixing ratios in increments of $1 \mathrm{hPa}$ and subsequently convert these into (1-hPa) $\mathrm{NO}_{2}$ subcolumns. Our 1-hPa bins typically contain 1-2 1-s measurements.

- For 1-hPa increments that have not been sampled by the LIF instrument, we linearly interpolate $\mathrm{NO}_{2}$ subcolumns between closest observed values. Fig. 2 shows three typical $\mathrm{NO}_{2}$ profiles $(1 \mathrm{~B}, 5 \mathrm{~B}$, and $6 \mathrm{~F})$ binned in $1-\mathrm{hPa}$ increments, along with their precisions described above. One-second data are outside of the precision curves for very few occasions, indicating that the precision estimates of $23-46 \mathrm{ppt}$ are on the conservative side.

- We extrapolate the average subcolumn over 10 1-hPa bins closest to the bottom altitude of the aircraft to the surface pressure obtained from the OMI measurements, thus conserving the $\mathrm{NO}_{2}$ subcolumn. The extrapolation is based on the observed subcolumns at the lowest aircraft altitudes, without making explicit assumptions on the extent of mixing in the unobserved part of the boundary layer. For profiles over complex terrain (16 and 19 March 2006) we obtained the surface pressure by adding $30 \mathrm{hPa}$ to the measured pressure of the aircraft at its lowest altitude, motivated by the DC- 8 bottom altitude being $0.3 \mathrm{~km}(1000 \mathrm{ft})$ above land. Likewise, we extrapolate the average subcolumn over $201 \mathrm{hPa}$ bins closest to the ceiling altitude of the aircraft to the tropopause pressure $(\sim 200 \mathrm{hPa})$. For profiles observed on flight 6 (19 March 2006), we used the observations of validation profile $6 \mathrm{~F}$ above the ceiling altitude, and subsequently extrapolated from 216 to $200 \mathrm{hPa}$.

- The sum of all $1 \mathrm{hPa}$ subcolumns from the (OMI) surface pressure to $200 \mathrm{hPa}$ is taken to be the tropospheric $\mathrm{NO}_{2}$ column.

We estimate relative errors in the DC- $8 \quad \mathrm{NO}_{2}$ columns between the bottom and top altitudes to be $10 \%$, accounting for a nominal LIF accuracy of $5-10 \%$ (Day et al., 2002) and interpolation errors. 

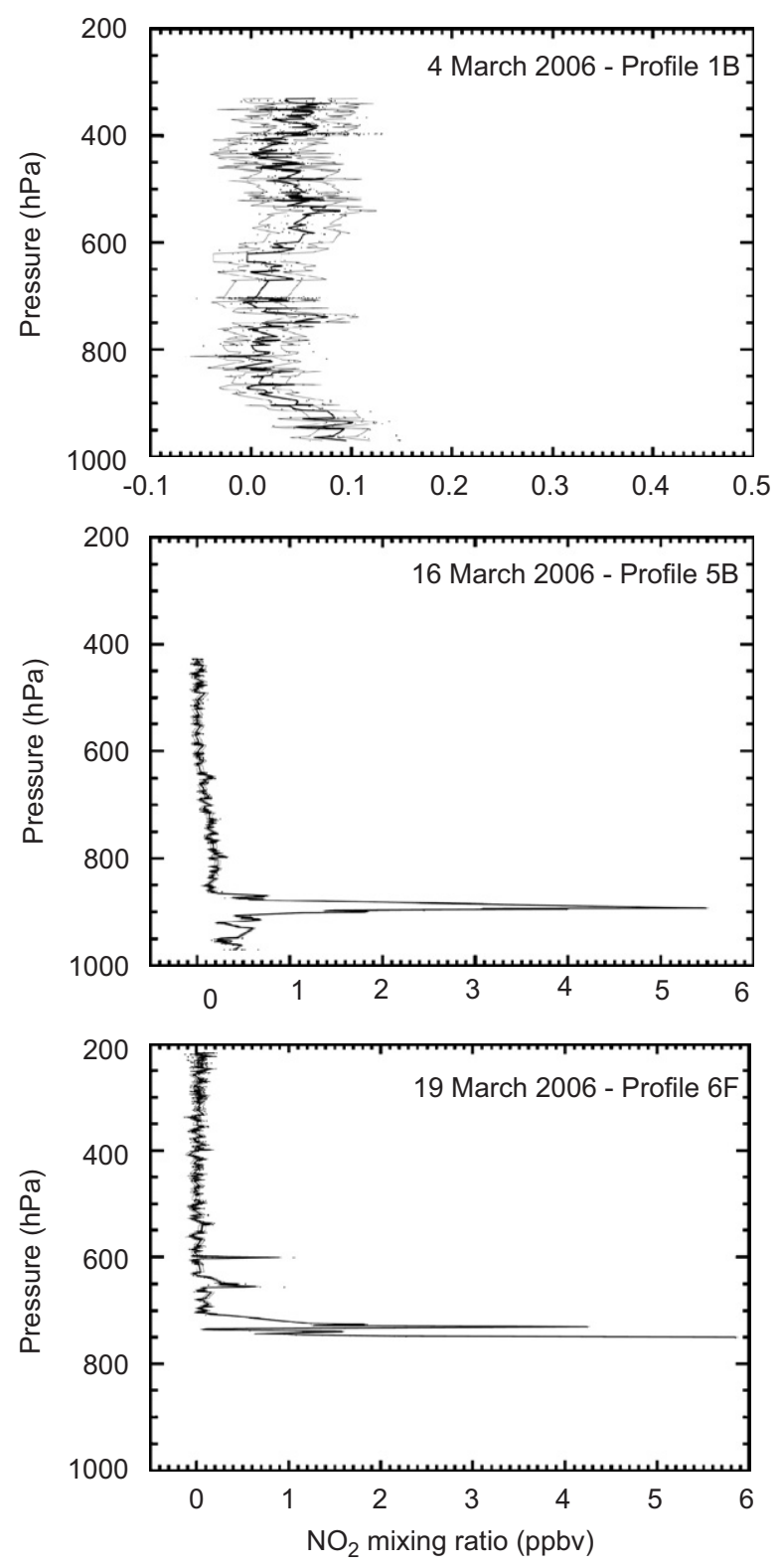

Fig. 2. Typical tropospheric $\mathrm{NO}_{2}$ profiles measured by the LIF from the DC-8 aircraft during the first phase of the INTEX-B campaign over the Gulf of Mexico. The center black line indicates the 1-hPa binned data, and the gray lines indicate the precision. Small dots represent 1-s data, and these lie generally well within the precision estimates. Further details on validation profiles can be found in Table 1 .

\subsection{Validation of results}

Fig. 1 shows monthly mean (March 2006) tropospheric $\mathrm{NO}_{2}$ columns from OMI observed on cloudfree (cloud radiance fractions $<50 \%$ ) days and locations over the INTEX-B domain. The circles indicate the location of the validation profiles over sea (white) and land (black). Table 1 gives the location, time, vertical coverage, and estimated DC-8 $\mathrm{NO}_{2}$ column for all validation spirals. Fig. 1 and Table 1 include a total of 21 cloud-free validation opportunities under conditions ranging from relatively clean (remote Gulf of Mexico, e.g. 1B) to strongly polluted (Mexico City, e.g. $6 \mathrm{E})$, although not yet covering the full dynamical range shown in the color bar of Fig. 1.

We averaged cloud-free (cloud radiance fraction $<50 \%$ ) OMI pixels over the spatial extent (OMI pixel center within $\pm 0.1^{\circ}$ of the spiral) of the DC-8 spirals for comparison to the DC- 8 tropospheric $\mathrm{NO}_{2}$ columns. We find up to 29 pixels per spiral. For columns derived from ascent or descent flights, we selected OMI observations over the spatial extent of the DC-8 flight where the LIF observed $\mathrm{NO}_{2}$ mixing ratios are in excess of $0.1 \mathrm{ppb}$. In practice this means that we select OMI pixels that are horizontally collocated with the portion of the DC-8 flight track that sampled the lowest part of the troposphere. This results in up to 19 pixels per ascent/descent. We compare the mean of collocated OMI $\mathrm{NO}_{2}$ columns to the DC-8 column and we approximate the uncertainty of the mean $\mathrm{OMI} \mathrm{NO}_{2}$ column by the standard deviation of the mean, accounting for variability due to random retrieval errors as well as spatial heterogeneity. Table 1 summarizes the information for each validation profile and shows the collocated OMI $\mathrm{NO}_{2}$ columns, their uncertainty and the number of pixels used.

The DC- 8 bottom altitude is $0.3 \mathrm{~km}(1000 \mathrm{ft})$ over land and $0.15 \mathrm{~km}(500 \mathrm{ft})$ over water. Over source regions, the lowest atmospheric layer is expected to have the highest $\mathrm{NO}_{2}$ mixing ratios. Extrapolating $\mathrm{NO}_{2}$ subcolumns from the bottom of the DC-8 profile down to the surface leads in a number of cases to high fractions $(>50 \%)$ of the tropospheric column originating from extrapolation. In these cases, where a significant part of the tropospheric $\mathrm{NO}_{2}$ column is unobserved, our estimates of the DC-8 tropospheric columns are particularly uncertain. We assume that the extrapolated fraction is $75 \%$ uncertain based on an analysis of GEOSChem simulations, which showed that, for given month, location and free-tropospheric column amount, the column variation in the lower troposphere is $\sim 75 \%$ (Eric Bucsela, private communication). The total uncertainty in DC- 8 columns can be expressed as $\varepsilon=0.1 \times N_{\mathrm{DC} 8}+0.75 \times N_{\mathrm{DC}_{\mathrm{ext}}}$, with 


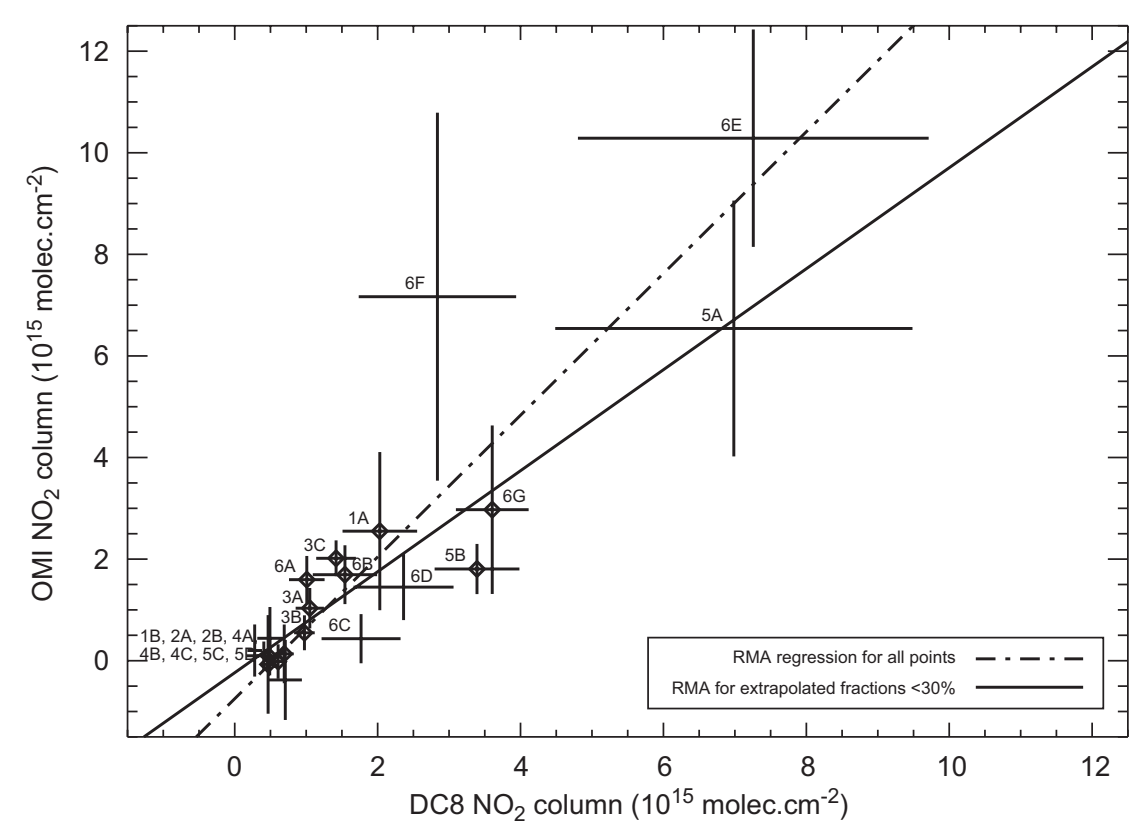

Fig. 3. Comparison of coincident OMI tropospheric $\mathrm{NO}_{2}$ columns with those determined from LIF in situ measurements from the DC-8 aircraft. Coincidences are labelled as in Fig. 1 and Table 1. Vertical bars are shown for illustration of the estimated OMI retrieval uncertainty, and horizontal bars for illustration of the estimated uncertainty of the DC-8 LIF measurements determined from in situ measurement uncertainty and extrapolation assumptions. The dashed line represents the reduced major axis regression through all data with a slope of $1.40 \pm 0.21\left(r^{2}=0.79\right)$. The solid line represents the reduced major axis (RMA) regression for situations when less than $30 \%$ of the DC-8 column has been extrapolated (diamonds) with a slope of $0.99 \pm 0.17\left(r^{2}=0.67\right)$.

$N_{\text {DC8 }}$ the observed column between the DC-8 bottom and top altitude, and $N_{\mathrm{DC} 8_{\mathrm{ext}}}$ the extrapolated column. The estimated uncertainties in the OMI and DC- 8 columns are illustrated as error bars in Fig. 3.

Fig. 3 shows the comparison of coinciding OMI and DC-8 tropospheric $\mathrm{NO}_{2}$ columns. The coefficient of determination, $r^{2}$, is $0.79(n=21)$. Because no clear distinction can be drawn between OMI and DC-8 tropospheric $\mathrm{NO}_{2}$ columns in terms of their dependency relations (both have considerable uncertainties that are uncertain themselves, see error bars in Fig. 3), we choose the reduced major axis (RMA, Clarke, 1980) regression method that minimizes the joint deviation of both variables from the regression model without attributing weights to the data. We find an $x$-axis intercept of $-0.75( \pm$ $0.23) \times 10^{15} \mathrm{~mol} \mathrm{~cm}^{-2}$ and a slope of $1.40( \pm 0.21)$. On average OMI observations preceded those by the DC- 8 by $11 \mathrm{~min}$ (RMS time difference: $109 \mathrm{~min}$ ). To reduce the effect of extrapolation assumptions on the comparison, we also compared OMI and DC-8 columns for situations where the extrapolated fraction of the DC- 8 column was $<30 \%$. For this subset, with column values $<4.0 \times 10^{15} \mathrm{~mol} \mathrm{~cm}^{-2}$, we find $r^{2}=0.67(n=12)$. The RMA regression now gives an $x$-axis intercept of $-0.24( \pm 0.18) \times$ $10^{15} \mathrm{~mol} \mathrm{~cm}^{-2}$ and a slope of $0.99( \pm 0.17)$. The values for the intercept and slope are different from the results obtained for the entire validation data set because the RMA regression does not attribute weights to the data points and the highly uncertain DC-8 columns with extrapolated fractions $>30 \%$ have now been removed. The negative intercepts that we find appear consistent with a low bias in OMI tropospheric $\mathrm{NO}_{2}$ reported by Boersma et al. (2008) over the Pacific Ocean, and we evaluate this further below.

We compare OMI retrievals with DC-8 validation flights over ocean only, with DC- 8 columns $<1.0 \times$ $10^{15} \mathrm{molcm}^{-2}(1 \mathrm{~B}, 2 \mathrm{~A}, 2 \mathrm{~B}, 4 \mathrm{~A}, 4 \mathrm{~B}, 4 \mathrm{C}, 5 \mathrm{C}$, and 5D). Fig. 4 shows a histogram of differences between 91 individual OMI pixels and the collocated DC-8 columns. OMI - DC- 8 differences were binned in increments of $0.2 \times 10^{15} \mathrm{~mol} \mathrm{~cm}^{-2}$. OMI generally observes lower columns and the difference can be fitted with a Gaussian distribution with median of approximately $-0.6 \times 10^{15} \mathrm{~mol} \mathrm{~cm}^{-2}$ and width (the distance from the median where the height of the curve is reduced to $\mathrm{e}^{-1 / 2}$ of its peak 


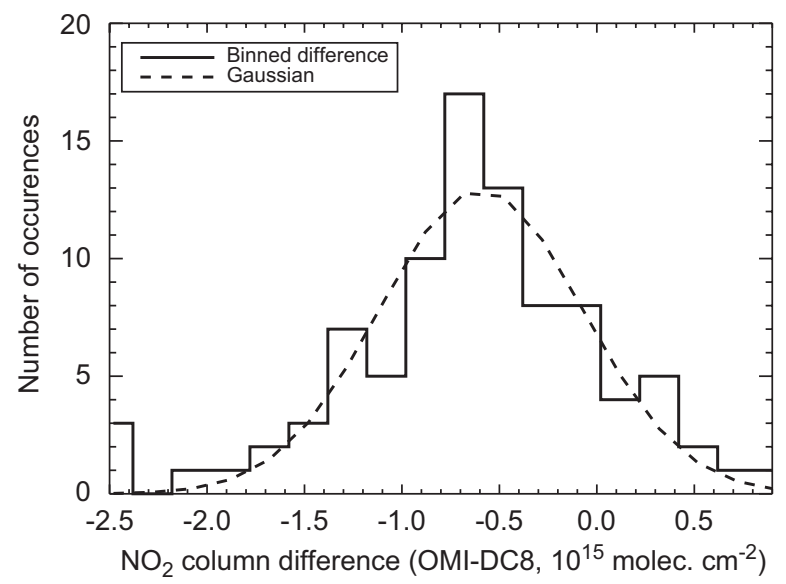

Fig. 4. Histogram of differences between individual OMI NRT tropospheric $\mathrm{NO}_{2}$ retrievals and coinciding DC-8 columns over oceans $\left(<1.0 \times 10^{15} \mathrm{~mol} \mathrm{~cm}^{-2}\right)$. Differences have been binned in increments of $0.2 \times 10^{15} \mathrm{~mol} \mathrm{~cm}^{-2}$. The dashed line represents a Gaussian distribution fitted to the differences.

value) of $\sim 0.5 \times 10^{15} \mathrm{~mol} \mathrm{~cm}^{-2}$. The median gives an estimate of the low bias in the OMI retrievals over ocean surfaces, and the width gives an estimate of the random error. The OMI bias estimate is consistent with that of Boersma et al. (2008) and the random error estimate is consistent with the previous error analyses by Boersma et al. (2004, 2007). The negative bias is not apparent in the slant columns, but is the result of subtracting stratospheric slant columns from the slant columns. Too high estimates for the stratospheric slant columns are likely related to errors in the (albedo, cloud) inputs to the assimilation procedure. Such input errors lead to too high values for the averaging kernel which in turn leads to too strong 'forcing' in the assimilation method (see Boersma et al., 2007), so that stratospheric slant columns will be overestimated. Indeed, there have been known problems with an early version of the $\mathrm{O}_{2}-\mathrm{O}_{2}$ cloud retrieval (0.9.43, www.knmi.nl/omi/research/product/Cloud/ OMCLDO2_history.html) used for v0.8 OMI $\mathrm{NO}_{2}$ data. These problems have been corrected in a more recent version of the $\mathrm{OMI} \mathrm{O}_{2}-\mathrm{O}_{2}$ algorithm that is being used in the latest OMI NRT $\mathrm{NO}_{2}$ retrievals.

We compare NRT OMI retrievals to DC-8 columns by Bucsela et al. (2008), who use different assumptions on integration and extrapolation. We find an intercept $-0.96( \pm 0.28) \times 10^{15} \mathrm{~mol} \mathrm{~cm}^{-2}$ and a slope of $1.84( \pm 0.40)(n=19)$. The higher slope is due to two distinct outliers over the Mexico City region, where Bucsela et al. (2008) extrapolate much smaller fractions than in this work. Over Mexico
City, the surface pressures in Bucsela et al. (2008) are not much different from the DC- 8 bottom altitude, whereas in this work the surface pressure is obtained by adding $30 \mathrm{hPa}$ to the measured pressure of the aircraft at its lowest altitude, motivated by the DC- 8 bottom altitude being $0.3 \mathrm{~km}$ (1000 ft) above land. Removing these two outliers, we find an intercept of $-0.56( \pm 0.37) \times 10^{15} \mathrm{~mol} \mathrm{~cm}^{-2}$ and a slope of $1.25( \pm 0.44)(n=17)$, in close agreement to our results. For a direct comparison of NRT and standard product retrievals of OMI tropospheric $\mathrm{NO}_{2}$ columns, and for a more detailed discussion of retrieval issues, including a comparison of a priori profiles used in OMI $\mathrm{NO}_{2}$ retrievals and actual DC8 measurements, we refer to the related paper by Bucsela et al. (2008).

\section{Top-down $\mathrm{NO}_{x}$ emission estimates from OMI}

We now use the OMI data to determine top-down surface $\mathrm{NO}_{x}$ emissions for March 2006 over the contiguous United States and Mexico, and compare to bottom-up inventories for the INTEX-B domain by the U.S. and Mexico Environmental Protection Agencies (US: 1999 National Emission Inventory (NEI99), northern Mexico: Big Bend Regional Aerosol and Visibility Observational (BRAVO, Kuhns et al., 2005) Study, southern Mexico: Global Emissions Inventory Activity (GEIA)) that are in use in global chemistry-transport models. We follow the approach by Martin et al. (2003), determining local top-down surface $\mathrm{NO}_{x}$ emissions $\left(E_{i, j}^{\mathrm{t}}\right.$, where the indices indicate the location of the grid cell) by scaling bottom-up $\mathrm{NO}_{x}$ emissions $\left(E_{i, j}^{\mathrm{b}}\right)$ by the ratio of the local retrieved $\left(N_{i, j}^{v}\right)$ and GEOS-Chem simulated $\mathrm{NO}_{2}$ columns $\left(N_{i, j}^{b}\right)$, sampled close to the satellite overpass time:

$E_{i, j}^{\mathrm{t}}=\frac{N_{i, j}^{v}}{N_{i, j}^{\mathrm{b}}} E_{i, j}^{\mathrm{b}}$.

GEOS-Chem uses the NEI99 and BRAVO/GEIA bottom-up inventories over the United States and Mexico and simulates $\mathrm{NO}_{2}$ columns at $2^{\circ} \times 2.5^{\circ}$ (see Appendix A). Because emitted $\mathrm{NO}_{x}$ may be transported from one grid cell to the other, this approach may lead to inferring spurious top-down emissions, especially for a region with weak emissions adjacent to a grid cell with strong emissions. The observed column at location $(i, j)$ is influenced by emissions from grid cell $(i, j)$ itself, and by emissions from adjacent grid cells, i.e. the column 
field is a smoothed representation of the underlying emission field. It is possible to simulate this smoothing without making explicit assumptions about meteorological parameters by the application of a kernel on the emission field:

$\alpha N_{i, j}^{v^{\prime}}=\sum_{m=-1}^{1} \sum_{l=-1}^{1} K_{l, m} E_{i+l, j+m}$

with $\alpha$ the ratio of $\mathrm{NO}_{x}$ emissions to $\mathrm{NO}_{2}$ columns (Martin et al., 2003), $N_{i, j}^{v^{\prime}}$ the approximated columns, and $E_{i, j}$ the emissions at grid cell $(i, j)$. Following Toenges-Schüller et al. (2006), the kernel is defined as

$\mathbf{K}=\frac{1}{k+8}\left(\begin{array}{lll}1 & 1 & 1 \\ 1 & k & 1 \\ 1 & 1 & 1\end{array}\right)$

with $k$ the smoothing parameter. For the domains of the eastern United States and Mexico, we find that a choice of $k=12$ maximizes the correlation between smoothed bottom-up emissions and the corresponding GEOS-Chem model column field. Substituting $N_{i, j}^{v^{\prime}}$ for $N_{i, j}^{v}$ in Eq. (1), rearranging terms, and assuming that the modelled smoothing is to first approximation representative for the actual smoothing $\left(E_{i j}=E_{i j}^{\mathrm{b}}\right)$, we find

$E_{i, j}^{\mathrm{t}^{\prime}}=\frac{E_{i, j}^{\mathrm{b}}}{\sum_{m=-1}^{1} \sum_{l=-1}^{1} K_{l, m} E_{i+l, j+m}^{\mathrm{b}}} \frac{N_{i, j}^{v}}{N_{i, j}^{\mathrm{b}}} E_{i, j}^{\mathrm{b}}$.

We subsequently use Eq. (3) to derive top-down $\mathrm{NO}_{x}$ emissions from OMI below.

\subsection{Eastern United States}

Fig. 5 compares the top-down inventory for March 2006 with the bottom-up inventory used in GEOS-Chem. Emissions from fuel combustion are from the U.S. EPA NEI99 inventory and account for $96.6 \%$ of U.S. $\mathrm{NO}_{x}$ emissions in March. Soil emissions (Yienger and Levy, 1995) account for $2.6 \%$ and biomass burning for $0.8 \%$. Lightning is negligible that time of year. Fig. 6 shows anthropogenic $\mathrm{NO}_{x}$ emissions from different source categories in NEI99. Transport accounts for 36\% of overall emissions, power plants for $25 \%$, other sources (mostly non-road vehicles) for $21 \%$, and industry for $17 \%$. The patterns exhibit only weak spatial correlation.

The top-down and NEI99 inventories have a high degree of consistency $\left(r^{2}=0.86, n=118\right)$. Fig. 5 shows that top-down $\mathrm{NO}_{x}$ emissions are especially smaller over the Ohio River valley, a region with strong emissions from power plants (upper right panel in Fig. 6). Over the northeastern United States, where transport emissions are significant, a number of grid cells show larger top-down emissions.

We exploited the difference in source patterns in Fig. 6 to determine the contributions of the individual source categories to the differences between the NEI99 and top-down inventories. We achieve this by a least-squares fit of a linear combination of the anthropogenic $\mathrm{NO}_{x}$ source patterns (shown in Fig. 6) to the reduced top-down inventory $\mathbf{E}_{\mathrm{t}}^{\prime}$ (written as a vector with emissions $E_{i, j}^{\mathrm{t}}$ as elements). The reduced inventory $\mathbf{E}_{\mathrm{t}}^{\prime}$ is obtained by subtracting the small soil, biomass burning, NEI99 aircraft and industrial solvent $\mathrm{NO}_{x}$ contributions from the top-down $\mathbf{E}_{\mathrm{t}}$. The modelled inventory $\left(\mathbf{E}_{\mathrm{mod}}\right)$ is written as

$\mathbf{E}_{\text {mod }}=\sum_{i=1}^{4} a_{i} \mathbf{E}_{i}$

Index $i=1$ represents industry, $i=2$ power plant, $i=3$ other (non-road vehicle and residential fuel burning), and $i=4$ on-road vehicle $\mathrm{NO}_{x}$ emissions. Since $\mathbf{E}_{\mathrm{mod}}$ is linear in its fit parameters $a_{i}, \| \mathbf{E}_{\mathrm{t}}^{\prime}-$ $\mathbf{E}_{\text {mod }} \|$ is minimized with a linear least squares method based on singular value decomposition (SVD, Press et al., 1986). Assuming that spatial patterns for the source categories have not changed dramatically between 1999 and 2006, $a_{i}$ are the multiplication coefficients that indicate the percategory change in emission strength between March 1999 and March 2006.

The minimization by SVD optimally reduces residuals $\mathbf{E}_{\mathrm{t}}^{\prime}-\mathbf{E}_{\text {mod }}$ for the set of fit coefficients $a_{1}=0.74, a_{2}=0.75, a_{3}=1.09$, and $a_{4}=1.30$ relative to $\mathbf{E}_{\mathrm{t}}^{\prime}-\mathbf{E}_{\mathrm{b}}$ (where $a_{1}=a_{2}=a_{3}=a_{4}=1.0$ ). The minimization $\left\|\mathbf{E}_{\mathrm{t}}^{\prime}-\mathbf{E}_{\text {mod }}\right\|$ reduces the chisquared statistic by $8 \%$ relative to $\left\|\mathbf{E}_{\mathrm{t}}^{\prime}-\mathbf{E}_{\mathrm{b}}\right\|$. Uncertainties in the fit coefficients have been determined with the bootstrap method by repeating our experiment 500 times replacing our original fields with a random sampling of the 118 grid cells. The coefficients $a_{i}$ have been computed for each random selection. The averages of the ensemble (with 500 members) reproduce the coefficients $a_{i}$ and the bootstrap standard errors represent the uncertainties in $a_{i}$. The bootstrap standard errors are $<0.02$ for all fit coefficients, and can be 

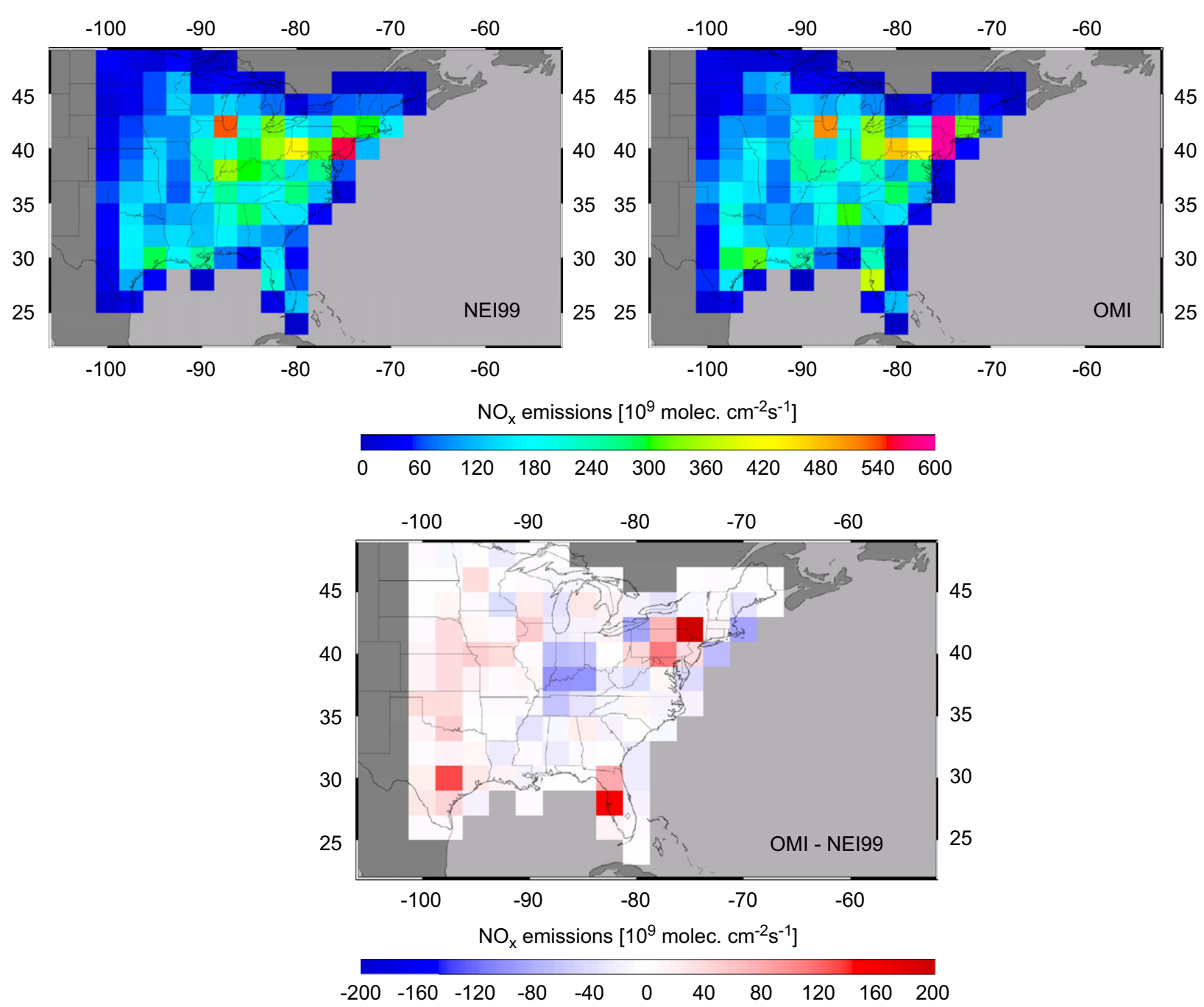

Fig. 5. Surface $\mathrm{NO}_{x}$ emissions at $2^{\circ} \times 2.5^{\circ}$ horizontal resolution for the eastern U.S. in March from the National Emission Inventory 1999 (upper left) and from the top-down emission inventory (upper right) for March 2006. Differences between the two inventories are shown on the bottom panel.

interpreted as empirical estimates of the uncertainty in the absence of systematic errors in the top-down emission inventory. Overall, we find a small increase of $3.2 \%$ in total $\mathrm{NO}_{x}$ emissions between March 1999 (NEI99, 0.452 Tg N) and March 2006 (topdown, $0.465 \operatorname{Tg} \mathrm{N}$ ), indicating that the increase in vehicular emissions is offsetting the reduction in power plant and industry emissions. We calculate the error in the top-down emission inventory following Martin et al. (2006) by adding in quadrature the error in the $\mathrm{OMI} \mathrm{NO}_{2}$ retrieval, and in the simulated $\mathrm{NO}_{x}$ emissions to $\mathrm{NO}_{2}$ column ratio. Retrieval uncertainties are $\pm\left(1.0 \times 10^{15} \mathrm{~mol}\right.$ $\mathrm{cm}^{-2}+30 \%$ ) for individual measurements as discussed in Section 2.2, but the uncertainty in the monthly mean is strongly reduced by averaging over large numbers of cloud-free OMI observations per $2^{\circ} \times 2.5^{\circ}$ grid cell (typically 50$)$ and over many days (typically 20 per grid cell). Fig. 3 (slope $0.99 \pm 0.17$ ) suggests that OMI observations may be biased by $17 \%$, and we adopt this number as the estimate for the error in the monthly mean $\mathrm{OMI} \mathrm{NO}_{2}$ columns. Previous comparison of GEOS-Chem simulations and observations (Li et al., 2004; Wang et al., 2004; Hudman et al., 2007) suggests that the model skill in calculating the emissions-to-column ratio is on the order of $20 \%$. The overall error in the topdown inventory is approximately $26 \%$, consistent with $25 \%$ errors recently reported by Wang et al. (2007b). 

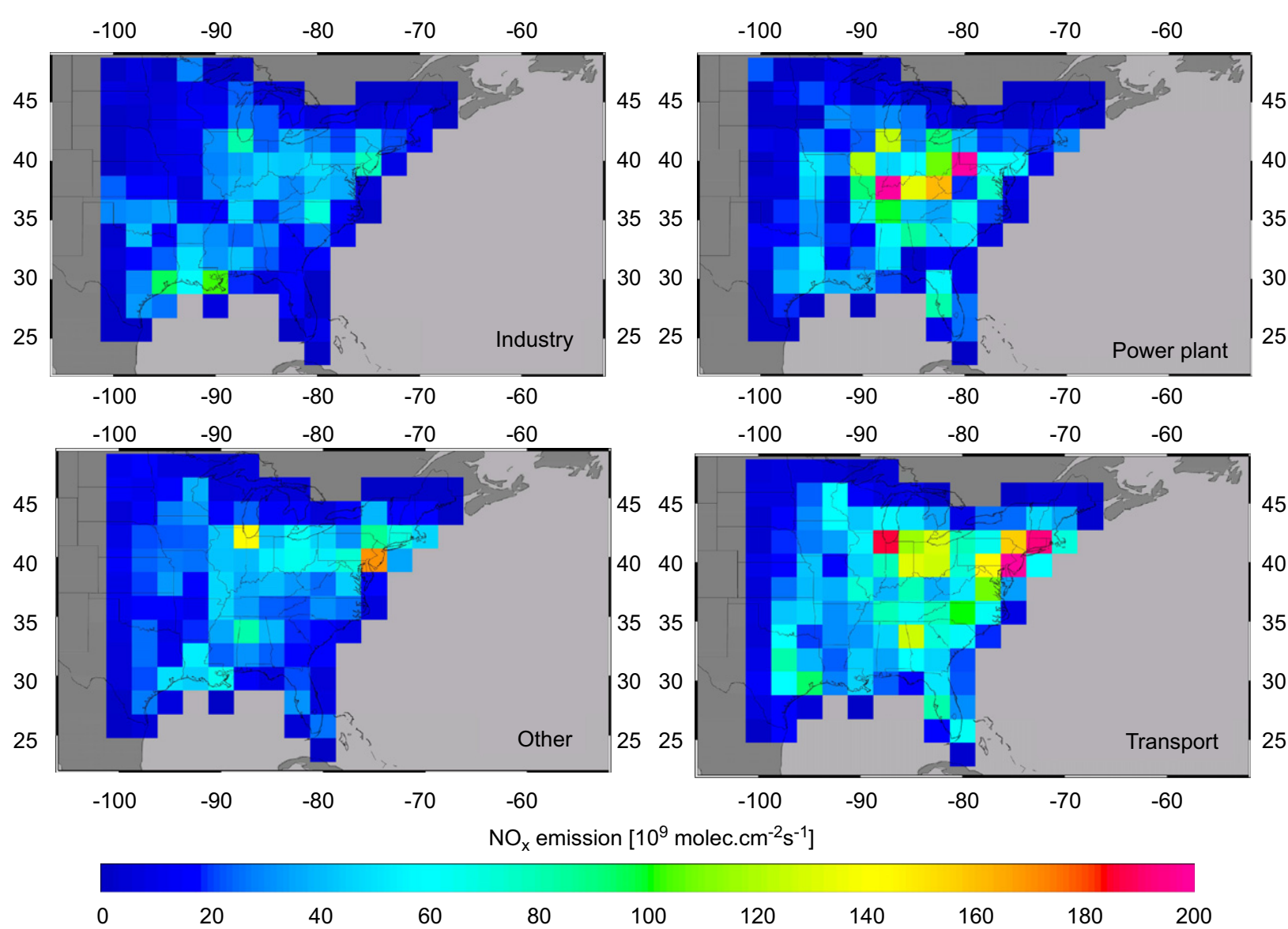

Fig. 6. Anthropogenic $\mathrm{NO}_{x}$ emissions for March from the industry, power plant, other, and transport source categories, as given by the U.S. Environmental Protection Agency National Emission Inventory for 1999 (NEI99), averaged on the $2^{\circ} \times 2.5^{\circ}$ grid of the GEOS-Chem model.

Large $(-50 \%)$ decreases in power plant $\mathrm{NO}_{x}$ emissions between the summer of 1999 and the summer of 2004 have been reported in the literature (Frost et al., 2006; Hudman et al., 2007), consistent with the Ozone Transport Commission $\mathrm{NO}_{x}$ Budget program and EPA's State Implementation Plan (SIP) Call that mandates reductions in $\mathrm{NO}_{x}$ point source emissions (mostly industry and power plants) during the so-called ozone season (May-September). Power utilities achieve these reductions by emission trading and technical control strategies that may remain in place outside the ozone season. We find a significant decrease $(-26 \%)$ in power plant $\mathrm{NO}_{x}$ emissions from March 1999 to March 2006. Similar decreases $(-20 \%$ to $-30 \%)$ between March 1999 and March 2004 have been found from monthly power plant $\mathrm{NO}_{x}$ emissions observed by EPA's Continuous Emission Monitoring System (CEMS) (G. Frost, personal communication, 2006).
Furthermore, Stavrakou and Müller (2006) found a $24 \%$ decrease in space-based $\mathrm{NO}_{x}$ emission estimates over the Indiana/Ohio river between March 1999 and March 2004.

Our inferred increase in on-road vehicle emissions $(+30 \%)$ is consistent with other recent results. Based on a critical evaluation of U.S. on-road vehicle inventories, Parrish (2006) infers an increase in $\mathrm{NO}_{x}$ emissions from on-road vehicles of $1.9 \% \mathrm{yr}^{-1}$ in the $1990 \mathrm{~s}$. Continued from 1999 to 2006, this increase in transport emissions would be $+14 \%$. Furthermore, Richter et al. (2005), van der A et al. (2006b), and Martin et al. (2006) show increasing tropospheric $\mathrm{NO}_{2}$ columns over the transport-dominated urban areas in the northeastern U.S., and decreasing columns in the powerplant dominated region of the Ohio River Valley from 1996 to 2004. The increase in transport (road vehicle) $\mathrm{NO}_{x}$ emissions may be due to increased 
diesel fuel consumption (Harley et al., 2005; Parrish, 2006). For the industry sector, subject to similar mandated emission reductions as the power plant sector, we find a similar decrease $(-25 \%)$ as for the power plant sector. For 'other' sources (mostly nonroad vehicles), we find an increase in $\mathrm{NO}_{x}$ emissions of $8 \%$ that coincides with the increase in on-road vehicle emissions.

Combining the bootstrap standard error and errors in the top-down emission inventory suggests errors in the fit coefficients of $25-30 \%$, comparable to the magnitude of the fitted coefficients themselves. These error estimates are likely too pessimistic. Comparison of our results to those of Frost et al. (2006) and Parrish (2006) indicates that any errors in our inferred changes are more likely to result from a high bias in the satellite retrievals or in modelled $\mathrm{OH}$ (or in both) than from low biases. We found little evidence for a low bias in the satellite measurements over land in Section 2. A low bias in the satellite measurements, in modelled $\mathrm{OH}$, or in both is even more unlikely because it would imply that our increase for on-road vehicle emissions $(+30 \%)$ and decrease $(-25 \%)$ for power plant emissions are underestimates of the actual changes, in stark contrast with results from Parrish (2006) $(+14 \%)$ and Frost et al. (2006) $(-30 \%$ to $-20 \%$ for 1999-2004). We therefore tentatively estimate the errors in the fit coefficients as $20 \%$.

After minimization of the differences $\left\|\mathbf{E}_{\mathrm{t}}^{\prime}-\mathbf{E}_{\text {mod }}\right\|$, there is still scatter $\left(r^{2}=0.87,13 \%\right.$ of the variance remains unexplained). This scatter is related to a number of individual cells with large differences, indicating areas where uncertainties of the bottomup and top-down fields are highest. Notable are the grid cells west of New York City, and west of Houston (Fig. 5). These areas were also identified as outliers in the EDGAR bottom-up inventory and a posteriori $\mathrm{NO}_{x}$ emissions from GOME as shown by Toenges-Schüller et al. (2006).

\subsection{Mexico}

Fig. 7 compares the top-down inventory with bottom-up inventories for Mexico. For the northern part of Mexico, enclosed by the white line in Fig. 7, as bottom-up we use the inventory developed for the Big Bend Regional Aerosol and Visibility Observational (BRAVO, Kuhns et al., 2005) Study for the year 1999. Outside of the BRAVO domain, we use anthropogenic emissions from the GEIA (Benkovitz et al., 1996) scaled by energy statistics to 1998.
Table 2 summarizes bottom-up $\mathrm{NO}_{x}$ emissions for Mexico assumed for all sources in the GEOS-Chem model. Soil $\mathrm{NO}_{x}$ emissions (Yienger and Levy, 1995) contribute $27 \%$ of bottom-up $\mathrm{NO}_{x}$ emissions over the BRAVO domain, and $19 \%$ over southern Mexico. Biomass burning $\mathrm{NO}_{x}$ emissions used in GEOS-Chem are from GFED-2 (van der Werf et al., 2006) for the latest year available (March 2004), with a magnitude of $1 \%$ of the bottom-up $\mathrm{NO}_{x}$ emissions over northern Mexico and $8 \%$ over southern Mexico.

The bottom-up and top-down inventories are spatially consistent $\left(r^{2}=0.84, n=36\right.$ for BRAVO, $r^{2}=0.77, n=20$ for GEIA with the Mexico City and Guadalajara grid cells left out). The right panel in Fig. 7 shows that top-down emissions are higher than bottom-up emissions throughout Mexico, with the largest differences for the Mexico City and Guadalajara grid cells. Table 2 summarizes the differences between bottom-up and top-down emissions. Top-down $\mathrm{NO}_{x}$ emissions are higher than the bottom-up emissions by a factor $2.0 \pm 0.5$ (see error discussion in Section 3.1) over the BRAVO domain and by a factor $2.3 \pm 0.6$ over southern Mexico. For comparison, total $\mathrm{NO}_{x}$ emissions (including soil $\mathrm{NO}_{x}$ emissions) from the recently released (October 2006) 1999 Mexico National Emissions Inventory (Environmental Protection Agency, 2006) are 1.8x higher than BRAVO for the 12 northern states, and $1.6 \times$ higher than GEIA for southern Mexico. Trend studies by Richter et al. (2005) and van der A et al. (2006b) do not show significant changes in $\mathrm{NO}_{2}$ concentrations over Mexico other than over Mexico City. This renders a strong increase in anthropogenic $\mathrm{NO}_{x}$ emissions throughout Mexico between March 1999 and 2006 unlikely. The total number of fire counts over the entire country in March 2006 was average compared to other years based on fire counts from FIRMS (2006) as shown by Wiedinmyer (personal communication, 2007). The spatial distribution of the difference between topdown and bottom-up $\mathrm{NO}_{x}$ emissions (Fig. 7) is reasonably correlated with the bottom-up soil $\mathrm{NO}_{x}$ emissions from Yienger and Levy (1995) over Mexico $\left(r^{2}=0.46, n=56\right)$. Bottom-up soil $\mathrm{NO}_{x}$ emissions over Mexico are lower by a factor of $\sim 4.5$ than top-down estimates in March 2006. This large underestimation of soil $\mathrm{NO}_{x}$ emissions from Yienger and Levy (1995) points to a problem already identified by Jaeglé et al. (2005) and Wang et al. (2007a) who found soil $\mathrm{NO}_{x}$ emissions inferred from GOME at mid-latitudes to be higher by 

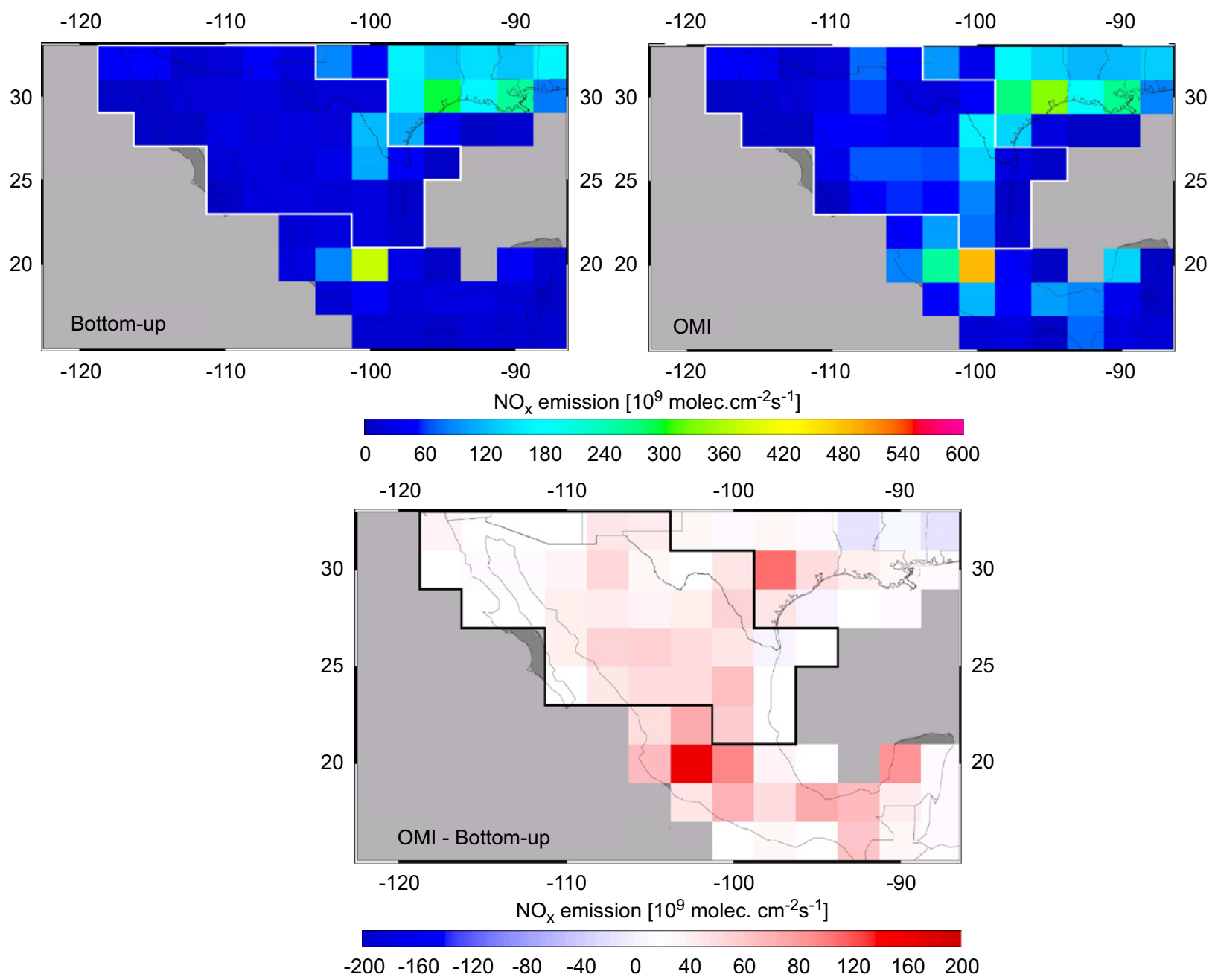

Fig. 7. Surface $\mathrm{NO}_{x}$ emissions at $2^{\circ} \times 2.5^{\circ}$ horizontal resolution for Mexico. The upper left panel shows BRAVO NO$x$ emissions over northern Mexico for 1999, indicated by the white line. The remaining grid cells over Mexico show GEIA emissions for March 1998. The upper right panel shows the top-down emission inventory for March 2006. Differences between the two inventories are shown on the bottom panel.

factors 3-5 than bottom-up emissions. Our results hold for March 2006, and appears to support these findings, although Bertram et al. (2005) have shown that discrepancies between bottom-up and topdown soil $\mathrm{NO}_{x}$ emissions may vary considerably from month to month due to difficulties in representing the timing of fertilizer application, and the influence of seasonally variable factors such as precipitation and temperature in the Yienger and Levy (1995) model.

For Mexico City and adjacent grid cell top-down $\mathrm{NO}_{x}$ emissions, we do not account for transport effects and apply Eq. (1). This is motivated by the unique topographical and meteorological situation of the Mexico City metropolitan area. Mexico City lies in an elevated basin, confined by mountain ridges $(\sim 1000 \mathrm{~m}$ higher than the basin) that, together with thermal inversions, are known to frequently prevent ventilation and trap pollutants within the Mexico City basin (e.g. Collins and Scott, 1993).

We find an overall emission strength of $17.4 \mathrm{Gg} \mathrm{N}$ for the Mexico City grid cell in March 2006, 27\% higher than the $13.7 \mathrm{GgN}$ from the bottom-up (shown in Fig. 7). Toenges-Schüller et al. (2006) and Martin et al. (2003) show annual $\mathrm{NO}_{x}$ emissions of 71-94 Gg N (2000) and 106-118 Gg N (1997) for their Mexico City grid cells, compared to $205 \mathrm{Gg} \mathrm{N}$ if we assume that our estimate for March holds for the complete year. Tropospheric $\mathrm{NO}_{2}$ columns have 
Table 2

$\mathrm{NO}_{x}$ emissions for March 2006 in Mexico

\begin{tabular}{|c|c|c|c|c|}
\hline \multirow[t]{2}{*}{ Source } & \multicolumn{4}{|l|}{ Emissions in $\mathrm{Gg} \mathrm{N}$} \\
\hline & Northern Mexico ${ }^{a}$ & Mexico City ${ }^{\mathrm{b}}$ & Southern Mexico & Mexico \\
\hline Anthropogenic & $18.2^{\mathrm{c}}$ & $13.3^{\mathrm{d}}$ & $14.7^{\mathrm{d}}$ & 46.2 \\
\hline Soil $^{\mathrm{e}}$ & 6.8 & 0.3 & 3.8 & 10.9 \\
\hline Biomass burning $^{\mathrm{f}}$ & 0.3 & 0.1 & 1.6 & 2.0 \\
\hline Total bottom-up & 25.3 & 13.7 & 20.1 & 59.1 \\
\hline Top-down ${ }^{\mathrm{g}}$ & 50.0 & 17.4 & 46.4 & 113.8 \\
\hline
\end{tabular}

\footnotetext{
${ }^{a}$ Northern Mexico is defined as the domain of the BRAVO emission inventory, shown as the region enclosed by the solid line in Fig. 7.

${ }^{\mathrm{b}}$ Mexico City refers to the grid cell in which Mexico City is located. Apart from Mexico City, this grid cell also contains the sizable cities of Toluca, Cuernavaca, and Morelia.

${ }^{\mathrm{c}}$ Bottom-up $\mathrm{NO}_{x}$ emissions (BRAVO) are for 1999 (Kuhns et al., 2005).

${ }^{\mathrm{d}}$ Bottom-up $\mathrm{NO}_{x}$ emissions (GEIA) are for March 1998 (Benkovitz et al., 1996; Bey et al., 2001).

${ }^{\mathrm{e}}$ Computed following Yienger and Levy (1995).

${ }^{\mathrm{f}}$ From GFED-2 for March 2004 (van der Werf et al., 2006).

${ }^{\mathrm{g}}$ Top-down emissions are estimated to be $26 \%$ uncertain; Section 3 .
}

increased from March 1998 to March 2006 by 6\% over the Mexico City grid cell (unpublished data from a trend analysis study by van der A et al., 2006a, consistent with Richter et al., 2005), too small to explain the differences between the March 2006 top-down and March 1999 bottom-up estimate. The comparison of $\mathrm{NO}_{2}$ columns from OMI and in situ measurements in Fig. 3 suggests that topdown $\mathrm{NO}_{x}$ emissions over Mexico City may be too high, but the high top-down $\mathrm{NO}_{x}$ emissions over Mexico City could also be related to large numbers of fires observed in the Mexico City metropolitan area in March 2006, as reported by Fast et al. (2007), and consistent with $3 \times$ higher fire counts (FIRMS, 2006) in March 2006 than the March 2002-2005 average (Wiedinmyer, personal communication, 2007).

\section{Summary and conclusions}

The first phase of the INTEX-B campaign during March 2006 provided extensive in situ observations of $\mathrm{NO}_{2}$ concentrations throughout the troposphere over the southern United States, the Gulf of Mexico, and the Mexican mainland including Mexico City. These included a number of aircraft spirals from 0.3 to $12 \mathrm{~km}$ altitude timed to coincide with overpasses of the Aura satellite and viewing scenes of the Ozone Monitoring Instrument (OMI) aboard Aura. We used these measurements to validate near-real time (NRT) OMI tropospheric $\mathrm{NO}_{2}$ columns and subsequently exploit the OMI
$\mathrm{NO}_{2}$ retrievals to put constraints on the sources of $\mathrm{NO}_{x}$ from the eastern United States and Mexico.

We found 21 coincidences between the tropospheric $\mathrm{NO}_{2}$ columns inferred from the DC-8 LIF instrument and retrieved from OMI over a range of cloud-free (cloud radiance $<50 \%$ ) conditions varying from the remote Gulf of Mexico to the heavily polluted Mexico City Metropole. For the subset of coincidences with small extrapolated fractions of the DC-8 column $(<30 \%)$, the two measurement techniques agree $\left(r^{2}=0.67\right.$, slope $\left.0.99, n=12\right)$. For the complete set $(n=21)$, including the most uncertain DC-8 columns, we find that OMI observes on average higher $\mathrm{NO}_{2}$ columns than inferred from the DC-8 $\left(r^{2}=0.79\right.$, slope 1.4). The subset of measurements over the remote Gulf of Mexico indicates that OMI NRT columns in relatively clean situations $\left(<1.0 \times 10^{15} \mathrm{~mol} \mathrm{~cm}^{-2}\right)$ have a small low bias $\left(0.6 \times 10^{15} \mathrm{~mol} \mathrm{~cm}^{-2}\right)$.

One limitation of the DC- 8 validation flights is that they cannot probe the very lowest part $(\sim 300 \mathrm{~m})$ of the planetary boundary layer. In order to avoid having to make assumptions on the amount of trace gas in the unobserved part, future satellite validation campaigns using aircraft measurements should attempt to provide as complete vertical sampling of the troposphere as possible. Horizontally, DC-8 validation spirals span multiple OMI satellite pixels, and the comparisons presented in our manuscript typically hold for footprints of hundreds of $\mathrm{km}^{2}$. To validate individual OMI retrievals, reducing the spatial extent of the satellite spiral would be required. Alternatively, the 
observed $\mathrm{NO}_{2}$ values from that part of the spiral that spatially coincides with an individual pixel could be compared, but assumptions on the unobserved part of the lower troposphere (where gradients may exist) would be needed.

We used the validated $\mathrm{OMI} \mathrm{NO}_{2}$ columns to provide top-down constraints on surface $\mathrm{NO}_{x}$ emissions over the eastern United States and Mexico in March 2006. Top-down emissions from OMI over the eastern United States are lower than bottom-up $\mathrm{NO}_{x}$ emissions from the U.S. EPA National Emissions Inventory for 1999 (NEI99), particularly over the industrial Midwest where emissions by power utilities are concentrated. In contrast, top-down emissions are on average higher than NEI99 emissions over the northeastern U.S., where emissions from on-road vehicles are dominant. Minimizing differences between the top-down and bottom-up emissions with a SVD-technique, we find reductions of $\sim 25 \%$ in power plant and industry emissions together with increases of $30 \%$ for on-road and $8 \%$ for non-road vehicle emissions for the 1999-2006 period assuming the inventory to be correct for 1999. The top-down estimate of $0.465 \mathrm{Tg} \mathrm{N}$ in March 2006 is 3.2\% higher than the NEI99 inventory of EPA (March 1999) over the eastern United States, indicating that the increase in vehicular emissions is countervailing the decrease in power plant and industry emissions. These findings, albeit with uncertainties of $20 \%$, are consistent with reductions in stationary sources between March 1999 and March 2004 observed on smokestacks (G. Frost, personal communication, 2006), and increases in $\mathrm{NO}_{x}$ emissions from on-road vehicles inferred from surface observations and emission inventories (Parrish, 2006).

Emission estimates from OMI for Mexico in March 2006 are a factor $2.0 \pm 0.5$ higher than bottom-up $\mathrm{NO}_{x}$ emissions. Comparing the bottomup inventory to the recently released Mexican NEI99 inventory shows that the latter is higher by a factor 1.6-1.8. There is little evidence that increases in $\mathrm{NO}_{x}$ emissions from 1999 to 2006 throughout Mexico underlie these differences (Richter et al., 2005). The inferred increases in Mexican $\mathrm{NO}_{x}$ emissions show reasonable spatial correlation $\left(r^{2}=0.46, n=56\right)$ with soil $\mathrm{NO}_{x}$ emissions (Yienger and Levy, 1995). Since biomass burning was average in March 2006 (except for the Mexico City region) and contributes less than $5 \%$ to overall $\mathrm{NO}_{x}$ emissions, higher top-down $\mathrm{NO}_{x}$ emission estimates over Mexico are supportive of the large underestimate in soil $\mathrm{NO}_{x}$ emissions that have been found in studies by Jaeglé et al. (2005) (factor 2-3) and Wang et al. (2007a), at least for March 2006. Over Mexico City, we find our topdown estimate to be higher by a factor 1.3, possibly related to above-average $\mathrm{NO}_{x}$ emissions from biomass burning in that area.

\section{Appendix A. GEOS-Chem}

We simulate tropospheric $\mathrm{NO}_{2}$ columns with the $2.5^{\circ} \times 2.0^{\circ}$ version of the global three-dimensional chemical transport model GEOS-Chem (v7-04-06; www-as.harvard.edu/chemistry/trop/geos/index.html) (Bey et al., 2001; Park et al., 2004). GEOS-Chem has been used for inverse modelling of $\mathrm{NO}_{x}$ emissions with satellite data by Martin et al. (2003), Jaeglé et al. (2005) and Martin et al. (2006), and we refer to these studies for more detailed descriptions of the model.

GEOS-Chem is driven by assimilated meteorological fields (GEOS-4) from the NASA Global Modeling Assimilation Office (GMAO) that are provided every $6 \mathrm{~h}$ ( $3 \mathrm{~h}$ for surface fields and mixing depths). There are 55 vertical sigma levels, extending up from the surface to $0.01 \mathrm{hPa}$. Below $2 \mathrm{~km}$, there are five levels. Chemical simulations are conducted at 30 vertical levels (stratospheric levels have been grouped) for March 2006 and have been initialized with an 8-month spin-up simulation.

GEOS-Chem uses national emission inventories for anthropogenic $\mathrm{NO}_{x}$ where available, and default values from the GEIA (Benkovitz et al., 1996) scaled by energy statistics to 1998 where not (Bey et al., 2001). Emissions in the United States are taken from the EPA 1999 National Emissions Inventory (NEI99, U.S. Environmental Protection Agency, 2001) with time-of-day and day-of-week variations based on Environmental Protection Agency (1989). Over northern Mexico, emissions are from the BRAVO inventory (Kuhns et al., 2005). Monthly mean biomass burning estimates are derived from satellite-observed fire counts combined with emission factors from Andreae and Merlet (2001) as described in van der Werf et al. (2006). Soil $\mathrm{NO}_{x}$ emissions are computed following Yienger and Levy (1995) with canopy reduction factors described by Wang et al. (1998).

GEOS-Chem includes a detailed simulation of $\mathrm{O}_{3}-\mathrm{NO}_{x}-\mathrm{CO}$-hydrocarbon-aerosol chemistry. The aerosol and gaseous simulations are coupled through the formation of sulphate and nitrate, the 
$\mathrm{HNO}_{3} / \mathrm{NO}_{3}^{-}$partitioning of total inorganic nitrate, and the uptake of $\mathrm{N}_{2} \mathrm{O}_{5}$ by aerosols in the presence of water vapor (the main night-time sink of $\mathrm{NO}_{x}$, modelled as in Evans and Jacob, 2005). The chemical timestep in the model is $1 \mathrm{~h}$, short enough to simulate diurnal photochemical changes in $\mathrm{NO}_{2}$ concentrations for comparison to OMI (overpass time of $\approx 13: 30$ local time).

\section{References}

Acarreta, J.R., De Haan, J.F., Stammes, P., 2004. Cloud pressure retrieval using the $\mathrm{O}_{2}-\mathrm{O}_{2}$ absorption band at $477 \mathrm{~nm}$. Journal of Geophysical Research 109, D05204.

Andreae, M.O., Merlet, P., 2001. Emission of trace gases and aerosols from biomass burning. Global Biogeochemical Cycles 15, 955-966.

Benkovitz, C.M., Scholtz, M.T., Pacyna, J., Tarrason, L., Dignon, J., Voldner, E.C., Spiro, P.A., Logan, J.A., Graedel, T.E., 1996. Global gridded inventories for anthropogenic emissions of sulphur and nitrogen. Journal of Geophysical Research 101, 29239-29253.

Bertram, T.H., Heckel, A., Richter, A., Burrows, J.P., Cohen, R.C., 2005. Satellite measurements of daily variations in soil $\mathrm{NO}_{x}$ emissions. Geophysical Research Letters 32, L24812.

Bey, I., Jacob, D.J., Yantosca, R.M., Logan, J.A., Field, B.D., Fiore, A.M., Li, Q., Liu, H.Y., Mickley, L.J., Schultz, M.G., 2001. Journal of Geophysical Research 106 (D9), 23073-23095.

Boersma, K.F., Bucsela, E.J., Brinksma, E.J., Gleason, J.F., 2002. $\mathrm{NO}_{2}$. In: Chance, K. (Ed.), OMI Algorithm Theoretical Basis Document, OMI Trace Gas Algorithms, vol. 4. ATBOMI-04, Version 2.0, NASA Distributed Active Archive Centers, Greenbelt, MD, August 2002, pp. 13-36.

Boersma, K.F., Eskes, H.J., Brinksma, E.J., 2004. Error analysis for tropospheric $\mathrm{NO}_{2}$ retrieval from space. Journal of Geophysical Research 109, D04311.

Boersma, K.F., Eskes, H.J., Veefkind, J.P., Brinksma, E.J., van der A, R.J., et al., 2007. Near-real time retrieval of tropospheric $\mathrm{NO}_{2}$ from OMI. Atmospheric Chemistry and Physics 7, 2103-2118.

Boersma, K.F., Jacob, D.J., Eskes, H.J., Pinder, R.W., Wang, J., van der A, R.J., 2008. Intercomparison of SCIAMACHY and OMI tropospheric $\mathrm{NO}_{2}$ columns: observing the diurnal evolution of chemistry and emissions from space. Journal of Geophysical Research, doi:10.1029/2007JD008816, in press.

Brinksma, E.J., et al., 2008. The 2005 and 2006 DANDELIONS $\mathrm{BO} 2$ and aerosol intercomparison campaigns. Journal of Geophysical Research, accepted for publication, doi:10.1029/ 2007JD008808.

Bucsela, E.J., Celarier, E.A., Wenig, M.O., Gleason, J.F., Veefkind, J.P., Boersma, K.F., Brinksma, E.J., 2006. Algorithm for $\mathrm{NO}_{2}$ vertical column retrieval from the Ozone Monitoring Instrument. IEEE Transactions on Geoscience and Remote Sensing 44 (5), 1245-1258 (special issue on the EOS Aura Mission).

Bucsela, E.J., Perring, A.E., Cohen, R.C., Boersma, K.F., Wenig, M.O., et al., 2008. A comparison of $\mathrm{NO}_{2}$ in situ aircraft measurements with data from the Ozone Monitoring Instru- ment. Journal of Geophysical Research, accepted for publication.

Clarke, M.R.B., 1980. The reduced major axis of a bivariate sample. Biometrika 67 (2), 441-446.

Cleary, P.A., Wooldridge, P.J., Cohen, R.C., 2002. Laser-induced fluorescence detection of atmospheric $\mathrm{NO}_{2}$ using a commercial diode laser and a supersonic expansion. Applied Optics 41 (33), 6950-6956.

Collins, C.O., Scott, S.L., 1993. Air pollution in the valley of Mexico. The Geographical Review 2, 119-133.

Day, D.A., Wooldridge, P.J., Dillon, M.B., Thornton, J.A., Cohen, R.C., 2002. A thermal dissociation laser-induced fluorescence instrument for in-situ detection of $\mathrm{NO}_{2}$, peroxy nitrates, alkyl nitrates, and $\mathrm{HNO}_{3}$. Journal of Geophysical Research 107, 4046.

Environmental Protection Agency, 1989. The 1985 NAPAP emission inventory (version 2): development of the annual data and modeler's tapes. EPA-600/7-89-012a, Research Triangle Park, NC.

Environmental Protection Agency, 2006. Executive summary. Mexico's National Emissions Inventory, 1999 /www.epa.gov/ $\mathrm{ttn} /$ chief/net/mexico.html>, 2006.

Evans, M.J., Jacob, D.J., 2005. Impact of new laboratory studies of $\mathrm{N}_{2} \mathrm{O}_{5}$ hydrolysis on global model budgets of tropospheric nitrogen oxides, ozone, and $\mathrm{OH}$. Geophysical Research Letters 32, L09813.

Fast, J.D., de Foy, B., Acevedo Rosas, F., Caetano, E., Carmichael, G., et al., 2007. A meteorological overview of the MILAGRO field campaigns. Atmospheric Chemistry and Physics 7, 2233-2257.

Fire Information for Resource Management System, 2006 〈http://maps.geog.umd.edu/firms/shapes.htm $\rangle$.

Frost, G.J., et al., 2006. Effects of changing power plant $\mathrm{NO}_{x}$ emissions on ozone in the eastern United States: proof of concept. Journal of Geophysical Research 111, D12306.

Harley, R.A., Marr, L.C., Lehner, J.K., Giddings, S.N., 2005. Changes in motor vehicle emissions on diurnal to decadal time scales and effects on atmospheric composition. Environmental Science and Technology 39, 5356-5362.

Heland, J., Schlager, H., Richter, A., Burrows, J.P., 2002. First comparison of tropospheric $\mathrm{NO}_{2}$ column densities retrieved from GOME measurements and in situ aircraft profile measurements. Geophysical Research Letters 29, 44.

Herman, J.R., Celarier, E.A., 1997. Earth surface reflectivity climatology at $340-380 \mathrm{~nm}$ from TOMS data. Journal of Geophysical Research 102, 28003-28011.

Hudman, R.C., Jacob, D.J., Turquety, S., Leibensperger, E.M., Murray, L.T., et al., 2007. Surface and lightning sources of nitrogen oxides in the United States: magnitudes, chemical evolution, and outflow. Journal of Geophysical Research 112, D12S05.

Jaeglé, L., Steinberger, L., Martin, R.V., Chance, K., 2005. Global partitioning of $\mathrm{NO}_{x}$ sources using satellite observations: relative roles of fossil fuel combustion, biomass burning and soil emissions. Faraday Discussion 130, 407-423.

Kim, S.-W., Heckel, A., McKeen, S.A., Frost, G.J., Hsie, E.-Y., Trainer, M.K., Richter, A., Burrows, J.P., Peckham, S.E., Grell, G.A., 2006. Satellite-observed U.S. power plant $\mathrm{NO}_{x}$ emission reductions and their impact on air quality. Geophysical Research Letters 33 (22), L22812.

Koelemeijer, R.B.A., Stammes, P., Hovenier, J.W., de Haan, J.F., 2001. A fast method for retrieval of cloud parameters 
using oxygen A-band measurements from the Global Ozone Monitoring Instrument. Journal of Geophysical Research 106, 3475-3490.

Koelemeijer, R.B.A., de Haan, J.F., Stammes, P., 2003. A database of spectral surface reflectivity in the range 335-772 nm derived from 5.5 years of GOME observations. Journal of Geophysical Research 108 (D2), 4070.

Kuhns, H., Knipping, E.M., Vukovich, J.M., 2005. Development of a United States-Mexico Emissions Inventory for the Big Bend Regional Aerosol and Visibility Observational (BRAVO) Study. Journal of the Air and Waste Management Association 55, 677-692.

Levelt, P.F., van den Oord, G.H.J., Dobber, M.R., Mälkki, A., Visser, H., de Vries, J., Stammes, P., Lundell, J.O.V., Saari, H., 2006. The Ozone Monitoring Instrument. IEEE Transactions on Geoscience and Remote Sensing 44 (5), 1093-1101.

Li, Q.B., Jacob, D.J., Yantosca, R.M., Munger, J.W., Parrish, D.D., 2004. Export of $\mathrm{NO}_{y}$ from the North American boundary layer: reconciling aircraft observations and global model budgets. Journal of Geophysical Research 109, D02313.

Martin, R.V., Chance, K., Jacob, D.J., Kurosu, T.P., Spurr, R.J.D., Bucsela, E., Gleason, J.F., Palmer, P.I., Bey, I., Fiore, A.M., Li, Q., Yantosca, R.M., Koelemeijer, R.B.A., 2002. An improved retrieval of tropospheric nitrogen dioxide from GOME. Journal of Geophysical Research 107 (D20), 4437.

Martin, R.V., Jacob, D.J., Chance, K.V., Kurosu, T.P., Palmer, P.I., Evans, M.J., 2003. Global inventory of nitrogen dioxide emissions constrained by space-based observations of $\mathrm{NO}_{2}$ columns. Journal of Geophysical Research 108, 4537.

Martin, R.V., Parrish, D.D., Ryerson, T.B., Nicks Jr., D.K., Chance, K., Kurosu, T.P., Jacob, D.J., Sturges, E.D., Fried, A., Wert, B.P., 2004. Evaluation of GOME satellite measurements of tropospheric $\mathrm{NO}_{2}$ and $\mathrm{HCHO}$ using regional data from aircraft campaigns in the southeastern United States. Journal of Geophysical Research 109, D24307.

Martin, R.V., Sioris, C.E., Chance, K., Ryerson, T.B., Bertram, T.H., Wooldridge, P.J., Cohen, R.C., Neuman, J.A., Swanson, A., Flocke, F.M., 2006. Evaluation of space-based constraints on global nitrogen oxide emissions with regional aircraft measurements over and downwind of eastern North America. Journal of Geophysical Research 111, D15308.

Ordóñez, C., Richter, A., Steinbacher, M., Zellweger, C., Nüß, H., Burrows, J.P., Prévôt, A.S.H., 2006. Comparison of 7 years of satellite-borne and ground-based tropospheric $\mathrm{NO}_{2}$ measurements around Milan, Italy. Journal of Geophysical Research 111, D05310.

Palmer, P.I., Jacob, D.J., Chance, K., Martin, R.V., Spurr, R.J.D., Kurosu, T.P., Bey, I., Yantosca, R., Fiore, A., Li, Q., 2001. Air-mass factor formulation for spectroscopic measurements from satellites: application to formaldehyde retrievals from the Global Ozone Monitoring Experiment. Journal of Geophysical Research 106, 14539-14550.

Park, R.J., Jacob, D.J., Field, B.D., Yantosca, R.M., Chin, M., 2004. Natural and transboundary pollution influences on sulphate-nitrate-ammonium aerosols in the United States: implications for policy. Journal of Geophysical Research 109, D15204.

Parrish, D.D., 2006. Critical evaluation of US on-road vehicle emission inventories. Atmospheric Environment 40, 2288-2300.
Press, W.H., Flannery, B.P., Teukolsky, S.A., Vetterling, W.T., 1986. Numerical Recipes. Cambridge University Press, Cambridge ISBN 0-521-30811-9.

Richter, A., Burrows, J.P., 2002. Retrieval of tropospheric $\mathrm{NO}_{2}$ from GOME measurements. Advances in Space Research 29, 1673-1683.

Richter, A., Burrows, J.P., Nüß, H., Granier, C., Niemeier, U., 2005. Significant increases in tropospheric nitrogen dioxide over China observed from space. Nature 437, 129-132.

Schaub, D., Boersma, K.F., Kaiser, J.W., Weiss, A.K., Folini, D., Eskes, H.J., Buchmann, B., 2006. Comparison of GOME tropospheric $\mathrm{NO}_{2}$ columns with $\mathrm{NO}_{2}$ profiles deduced from ground-based in situ measurements. Atmospheric Chemistry and Physics 6, 3211-3229.

Schaub, D., Brunner, D., Boersma, K.F., Keller, J., Folini, D., Buchmann, B., Berresheim, H., Staehelin, J., 2007. SCIAMACHY tropospheric $\mathrm{NO}_{2}$ over Switzerland: estimates of $\mathrm{NO}_{x}$ lifetimes and impact of the complex Alpine topography on the retrieval. Atmospheric Chemistry and Physics 7, 5971-5987.

Stammes, P., 2001. Spectral radiance modeling in the UV-Visible range. In: Smith, W.L., Timofeyev, Y.J. (Eds.), IRS2000: Current Problems in Atmospheric Radiation. A. Deepak, Hampton, VA, USA, pp. 385-388.

Stavrakou, J., Müller, J.-F., 2006. Multi-year grid-based inversion of $\mathrm{NO}_{x}$ emissions in a global CTM. Eos Transactions AGU, vol. 87(52), Fall Meeting Supplement, Abstract A31B0876.

Thornton, J.A., Wooldridge, P.J., Cohen, R.C., 2000. Atmospheric $\mathrm{NO}_{2}$ : in situ laser-induced fluorescence detection at parts per trillion mixing ratios. Analytical Chemistry 72, 528-539.

Thornton, J.A., Wooldridge, P.J., Cohen, R.C., Williams, E.J., Hereid, D.P., Fehsenfeld, F.C., Stutz, J., Alicke, B., 2003. Comparisons of in situ and long path measurements of $\mathrm{NO}_{2}$ in urban plumes. Journal of Geophysical Research 108, 4496.

Toenges-Schüller, N., Stein, O., Rohrer, F., Wahner, A., Richter, A., Burrows, J.P., Beirle, S., Wagner, T., Platt, U., Elvidge, C.D., 2006. Global distribution pattern of anthropogenic nitrogen oxide emissions: correlation analysis of satellite measurements and model calculations. Journal of Geophysical Research 111, D05312.

United States Environmental Protection Agency (U.S. EPA), 2001. National Air Quality and Emissions Trends Report, 1999, EPA 454/R-01-004, Office of Air Quality Planning and Standards, Research Triangle Park, NC.

van der A, R.J., Peters, D.H.M.U., Eskes, H., Boersma, K.F., Van Roozendael, M., DeSmedt, I., Kelder, H.M., 2006a. Detection of the trend and seasonal variation in tropospheric $\mathrm{NO}_{2}$ over China. Journal of Geophysical Research 111, D12317.

van der A, R.J., Eskes, H.J., Van Roozendael, M., DeSmedt, I., Blond, N., Boersma, K.F., Weiss, A., 2006b. Algorithm Document Tropospheric $\mathrm{NO}_{2}$. TEM/AD1/001, De Bilt, the Netherlands, January 2006 〈www.temis.nl/airpollution no2.html $\rangle$.

van der Werf, G.R., Randerson, J.T., Giglio, L., Collatz, G.J., Kasibhatla, P.S., Arellano, A.F., 2006. Interannual variability in global biomass burning emissions from 1997 and 2004 Atmospheric Chemistry and Physics 6, 3423-3441.

van Noije, T.P.C., Eskes, H.J., Dentener, F.J., Stevenson, D.S., Ellingsen, K., et al., 2006. Multi-model ensemble simulations 
of tropospheric $\mathrm{NO}_{2}$ compared with GOME retrievals for the year 2000. Atmospheric Chemistry and Physics 6, 2943-2979.

Wang, Y., Jacob, D.J., Logan, J.A., 1998. Global simulation of tropospheric $\mathrm{O}_{3}-\mathrm{NO}_{x}$-hydrocarbon chemistry: 1. Model formulation. Journal of Geophysical Research 103, 10713-10726.

Wang, Y.X., McElroy, M.B., Wang, T., Palmer, P.I., 2004. Asian emissions of $\mathrm{CO}$ and $\mathrm{NO}_{x}$ : constraints from aircraft and Chinese station data. Journal of Geophysical Research 109, D24304.

Wang, Y.X., McElroy, M.B., Martin, R.V., Streets, D.G., Zhiang, Q., Fu, T.-M., 2007a. Seasonal variability of $\mathrm{NO}_{x}$ emissions over east China constrained by satellite observations: implications for combustion and microbial sources. Journal of Geophysical Research 112, D06301.
Wang, Y.X., McElroy, M.B., Boersma, K.F., Eskes, H.J., Veefkind, J.P., 2007b. Traffic restrictions associated with the Sino-African summit: reductions of $\mathrm{NO}_{x}$ detected from space. Geophysical Research Letters 34, L08814.

Wenig, M.O., Cede, A.M., Bucsela, E.J., Celarier, E.A., Boersma, K.F., Veefkind, J.P., Brinksma, E.J., Gleason, J.F., Herman, J.R., 2008. Validation of OMI tropospheric $\mathrm{NO}_{2}$ column densities using direct sun mode Brewer measurements at NASA Goddard Space Flight Center. Journal of Geophysical Research, accepted for publication.

Yienger, J.J., Levy, H., 1995. Empirical model of global soilbiogenic $\mathrm{NO}_{x}$ emissions. Journal of Geophysical Research $100,11447-11464$. 